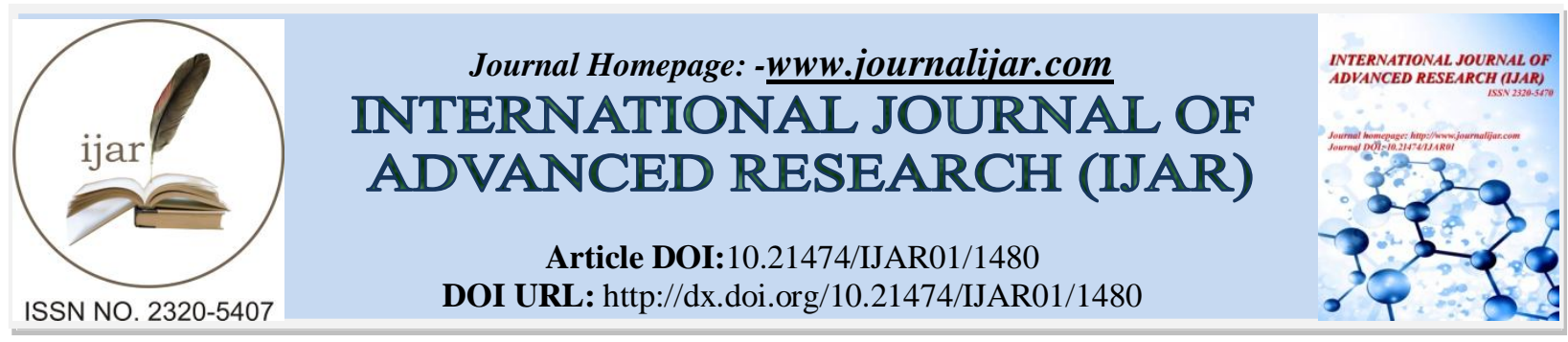

RESEARCH ARTICLE

\title{
TECTONIC CLASSIFICATION OF DHARWAR CRATON, INDIA.BASED ON INVERSION OF REGIONAL BOUGUER GRAVITY.
}

\author{
Ramadass.G and Bhagya.K. \\ Center of Exploration Geophysics, Osmania University, Hyderabad.
}

\section{Manuscript Info}

Manuscript History

Received: 12 July 2016

Final Accepted: 16 August 2016

Published: September 2016

Key words:-

Crustal configuration, anticlines,

synclines, up warps, plunging, Inversion

\section{Abstract}

Regional Bouguergravity data along eleven traverse $\left(73^{\circ} 30^{\prime} \mathrm{E}\right.$ to $78^{\circ}$ $30^{\prime} \mathrm{E}$ and latitude $12^{\circ} \mathrm{N}$ to $17^{\circ} \mathrm{N}$ ) across the Dharwar craton data have been analyzed to estimate the deeper crustal configurations. The tectonic differentiation was elucidated on a four layered earth model, constituted a Peneinsular gneisses, Upper and Deeper crustal and Moho layers. Four deep seated faults extending down to Moho were inferred. Running west to east, the First (FI) western part, the second fault F-II corresponds to Bababudan - Nallurshear, the third fault FIII runs along the western margin of closepet batholith and last fourth fault F-IV lies eastern part of the study area.

These faults suggest a modified Tectonic classification of the Dharwar Craton we here inferred a Western Dharwar Craton (WDC) bounded it west FII fault (Bababudan Fault) and Eastern Dharwar Craton block east of the FIII fault (EDC), with an Intervening block (IB) in between FII and FIII. The Chitradurga thrust fault (CT), hitherto believe to divide the Dharwar Craton into the two fold classification that is EDC, WDC is inferred to extent only the Gneissic basement rather than being deep seated.

The crustal thickness of the each of the tectonic blocks indentified view, west of fault FI, FI- FII, FII - FIII, FIII - FIV and East of FIV depth ranges varies from $32.98-38.3 \mathrm{Km}, 34.71-39 \mathrm{Km}, 34.21-35.86$ $\mathrm{Km}, 34.77-38.74 \mathrm{Km}$ and $33.11-38 \mathrm{Km}$, respectively the average crustal thickness for the West Dharwar Craton (WDC) is 39. Km, Intervening block $34.5 \mathrm{Km}$ and Eastern Dharwar Craton (EDC) 37. Km the crustal thickness beneath the Chitradurga fault (CT) which lies middle of Intervening block is about $34 \mathrm{Km}$.

Copy Right, IJAR, 2016,. All rights reserved.

\section{Introduction and Geology:-}

The Dharwar Craton is split into eastern and western cratons with major differences in lithology and ages of rock units. The western boundary of the Eastern Dharwar Craton (EDC) is poorly defined and is constrained to a $200 \mathrm{~km}$ wide lithologic transitional zone from the Peninsular Gneisses of the Western Dharwar Craton to the Closepet Granite.

The tectonic framework of South Indian shield region (SISR) has been studied by various geological and geophysical methods and reviewed by various workers (e.g. Mishra, 2011; Drury and Holt, 1980; Drury et al., 1984; 
Radhakrishnan, 2003; Santhosh et al.,2003,2005). Earlier geophysical studies in the Dharwar craton include gravity (Subrahmanyam, 1978; HariNarain and Subrahmanyam, 1986; Krishnabrahmam, 1993; Mishra and Rao, 1993; Mishra and Venkatarayduu, 1985). Gravity and Magnetic (Qureshy et al., 1967; Kaila \& Bhatia, 1981, Mishra \&Prajapati, 2003, Sing et al., 2004, Kumar et al.,2012), deep seismic soundings (DSS) (Kaila et al., 1979; Reddy et al., 2000, Kaila et al., 1992, Mishra et al., 2006, Gaur and Priestley, 1997; Raiet al., 2003; Gupta etal., 2003a, b; Sarkar et al., 2003), Aeromagnetic Reddy et al.(1988) and tomographic (Srinagesh\&Rai, 1996; Gupta, 2003), Magneto- telluric (Gokarn et al., 1998, 2004). Petrophysical and crustal configuration (Ramadass et al., 2002, 2006), and heat flow (Gupta, 1987) investigations.contributed immensely in reconstructing the geological history of the Dharwar craton.

Geologically the Dharwar Craton well documented (Naqvi\& Rogers, 1987; Rajamani, 1990; Chadwick et al., 2000). The Closepet Granite is a good approximation of the western boundary (Ramakrishna and Vidyanadhan, 2008). On the other hand, Drury and Holt (1980), Drury et al. (1984) and Chadwick et al. (2000) have suggested that the Chitradurga shear zone (CT in Fig. 1) divides the craton into the eastern and western blocks. Similar inferences were arrived at from deep seismic sounding (DSS) studies by Kaila et al. (1979), from analysis of seismic wave velocities, Reddy et al. (2000) also reported that the upthrust zone along the Chitradurga boundary thrust fault marked this major contact. However, while the sub units of the craton are generally recognized, there is some disagreement on the exact location and nature of the boundary separating them. Essentially two different boundaries have been proposed. Naqvi and Rogers (1987) suggested that the Closepet granitic batholith formed the boundary between the eastern and western Dharwar cratons. However, the nature of the Closepet batholith itself is open to debate: while Swaminath et al. (1976) and Ramakrishnan et al. (1976) have opined that it represents a major geosuture, Narayanaswami (1970) presented it as a geo-anticlinal ridge.

The Dharwar craton has been divided tectonically in to Eastern and western Dharwar craton by Ramakrishna et al (1976) andSwaminath et al (1976).

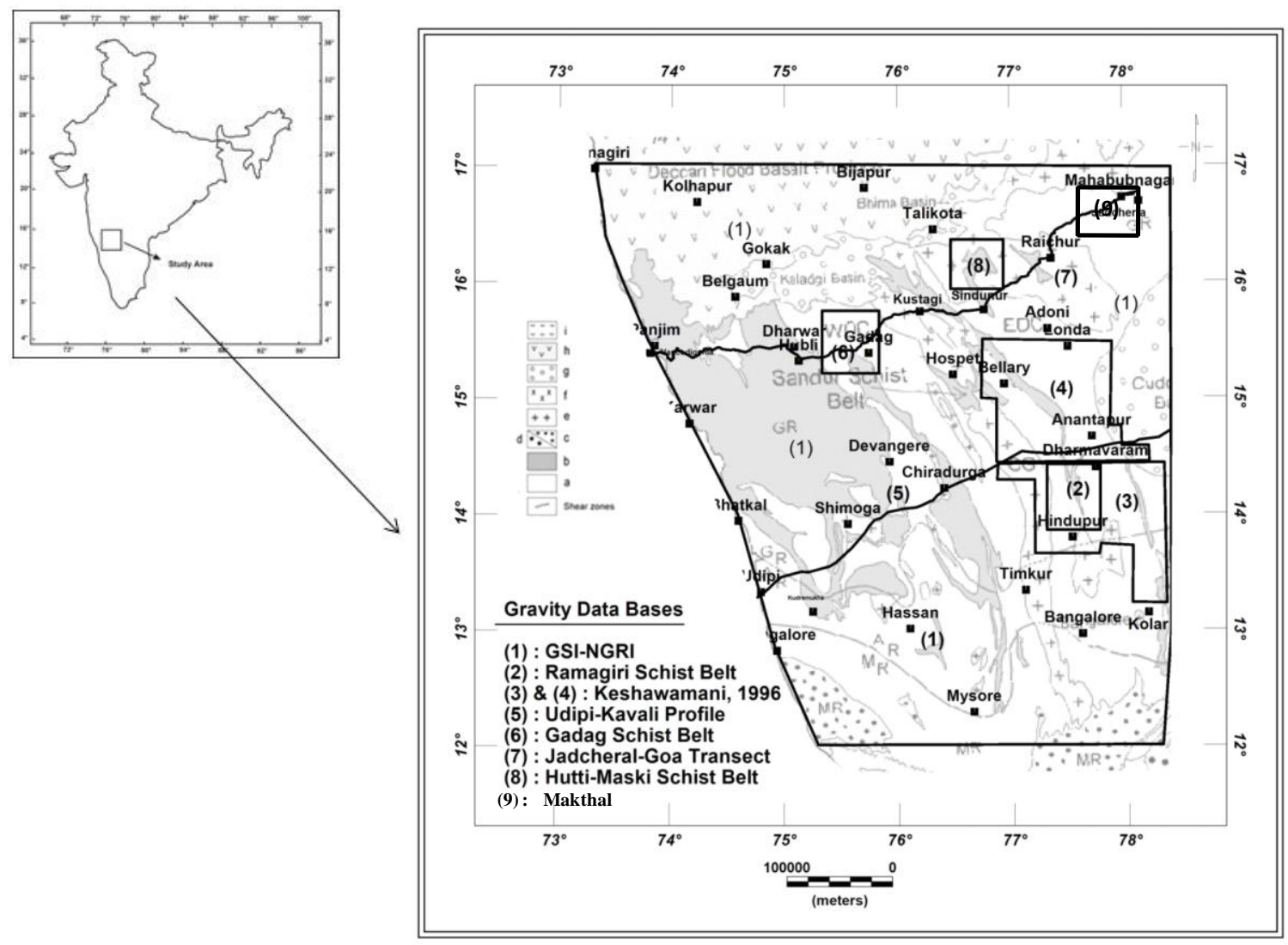

Figure.1:- Geology map of the Study Area (Bhagya and Ramadass 2016). 
Ramadass et al 2006 proposed that the craton are divided into three distinct blocks western and eastern blocks separated by an intervening block within the region between the Bababudan-Nallur shear and the western margin of the Clospet batholith. This model so conceived, is at variance with the current perception of the configuration of the Dharwar craton. Sunder Raju (2014) postulate a central Dharwar block occur in between western and eastern Dharaar block, Jayanada et al (2013) have called this transition zone as Middle Dharwar Craton, Mohan et al (2013) support this model.

The Western Dharwar Craton (WDC) is located in southwest India and is bound to the east by the Eastern Dharwar Craton (EDC), to the west by the Arabian Sea, and to the south by a transition into the so-called "Southern Granulite Terrain". The remaining boundary to the north is buried under younger sediments and the Cretaceous Deccan Traps. The division between the Western and Eastern Dharwar Cratons is based on the nature and abundance of greenstones, as well as the age of surrounding basement and degree of regional metamorphism (Rollinsonet al., 1981). The Western Dharwar Craton is an ancient terrain distributed by an olden Sargur Orogeny involving the lithological assemblage (WDC) contains two types of supra crustal groups of the WDC, the oldest recognized Sargur group occurs as widely dispersed enclaves within the gneisses where as the younger supra crustal (3 to 2.5 $\mathrm{Ga}$ old i.e. essentially late Achaean) of the Dharwar supergroup, namely the Bababudhan, Shimoga and Chitradurga groups, occur as large belts comparable to Proterozoic basins and geosynclines. The southern part of the Western Dharwar Craton (WDC) contains a number of metamorphosed ultramafic bodies, many of which form large intrusive complexes.

Eastern Dharwar Craton( EDC) is bounded to the north by the Deccan Traps and the Bastar Craton, to the east by the Eastern Ghats Mobile Belt, and to the south by the Southern Granulite Terrain (Balakrishnanet al., 1987). The Craton is composed of the Dharwar Batholith (dominantly granitic), greenstone belts, intrusive volcanic, and middle Proterozoic to more recent sedimentary basins (Ramakrishnan and Vaidyanadhan, 2008). The supra crustal belts of the Eastern block of the Dharwar Craton are smaller in size than those of the western blocks which are surrounded by gneisses and granites. The prominent greenstone belts of the Eastern Block include Kolar, Sandur and Hutti. These belts contain supracrustal rocks essentially made up of volcanic rocks with subordinate amounts of sedimentary rocks composed of quartzites, polymict, conglomerate, carbonates, $\mathrm{BCF} / \mathrm{BIF}$ and $\mathrm{Mg}$-rich peletic rocks and phyllites.

\section{Gravity Data Base:-}

New gravity data was collected 601 observation points along > $600 \mathrm{Km}$ from Panaji to Jedcherla transect, 941 at Gadag gravity observations and 548 observation were observed at Makthal a total of 2180 observation points were acquired by CEG, OU with a station interval of $1 \mathrm{Km}$ with a Lacoste-Romberg (Model-G-940) gravimeter with an accuracy of $0.1 \mathrm{mGal}$ (Ramdass et al., 2006). After all corrections applied to data and it was concentrated in filing the gap and merging 2180 new observations with 10,000 existing Udipi-Kavali transect data from NGRI (Singh et al., 2003, 2004) and GSI (Keshawamani, 1996, 1999; Appa Rao, 1995), Central of Exploration Geophysics (Ramadass et al., 2003, 2006) shown in Figure.1 . In fact, a further increase in the density and accuracy of observations might provide more information about the structure of the Craton.

\section{Analysis of Gravity:-}

The Part of the Bouguer gravity map of India Shield (Singh et al., 2003,2004; Keshawamani, 1996, 1999; Appa Rao, 1995; Ramadass et al., 2003, 2006; Mishra, 2011), on 1:100,000 scale is presented in Fig 2, between longitude $73^{\circ} 30^{\prime} \mathrm{E}$ to $78^{\circ} 30^{\prime} \mathrm{E}$ and latitude $12^{\circ} \mathrm{N}$ to $17^{\circ} \mathrm{N}$. Interpretation of the Bouguer gravity data of South India correlating all the geologically provinces has been carried out by many workers, in particular Subrahmanyam (1978),

New gravity investigations were carried out between the $73^{\circ} 30^{\prime} \mathrm{E}-78^{\circ} 30^{\prime} \mathrm{E}$ Longitudes and $12^{\circ} \mathrm{N}-17^{\circ} \mathrm{N}$ Latitudes in the Dharawarcraton from qualitative analysis (Bouguer gravity) several faults/lineaments are determined ( Bhagya and Ramadass. 2016). The gravity over the Dharwar Craton has range of $-20 \mathrm{mGal}$ to $-130 \mathrm{mGal}$ near Hassan it is characterized by conspicuous highs and lows alternating and trending NE-SE direction. The gravity high (positive) in most cases are invariably with greenstone belts, while gravity lows (negative) optional occur over granite outcrops and younger granites. The Dharwar, Shimgoa, Bababudan (BN) belts is a wider and shallower basin; it is representing in Bouguer anomaly. 
Further, north of the study area Deccan Volcanic (DVP) Province (Bhagya and Ramadass 2014) also brought out the structural configuration of the region. Broadly all lineaments appear to follow the preferred direction NW-SE, NS and NE-SW, the major structural features over the NW-SE Western Ghats (F3) and Kurdwar low (L7) was identified.

The Quantitative inversion modeling of the Bouguer gravity data in the Dharwar Craton area was to structural configuration of the area from the inversion of 11-West-East profiles parallel to $12^{\circ}$ to $17^{\circ} \mathrm{E}$ Traverse $\mathrm{T} 1, \mathrm{~T} 2, \mathrm{~T} 3, \mathrm{~T} 4, \mathrm{~T} 5, \mathrm{~T} 6, \mathrm{~T} 7, \mathrm{~T} 8, \mathrm{~T} 9, \mathrm{~T} 10$ and T11) at an interval of every half degree and separated from each other by a NorthSouth direction of $55 \mathrm{~km}$ running from South to North digitized from the Bouguer Gravity map Fig (2).

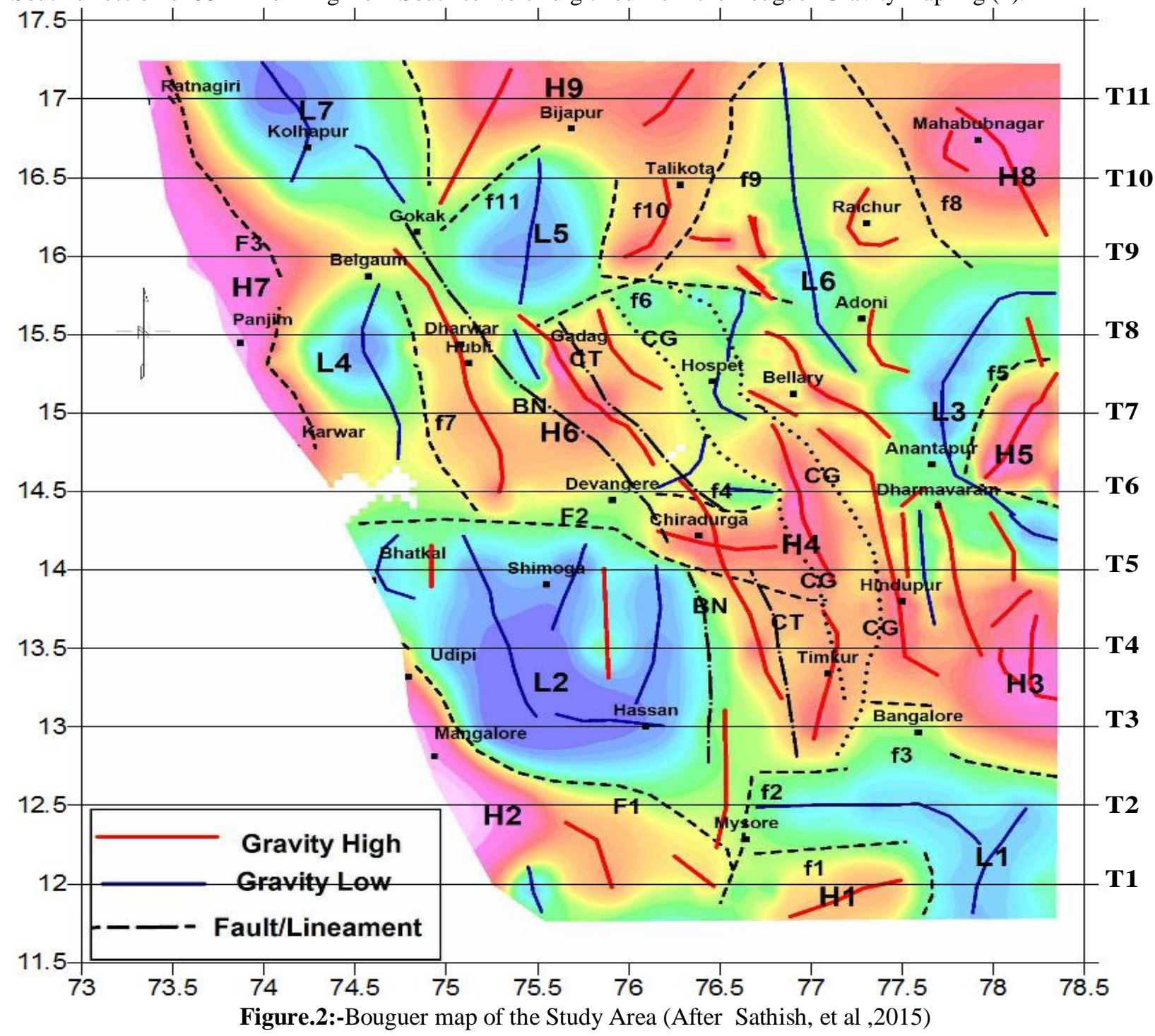

Modeling with Bouguer Gravity Regional:-

As the regional anomalies are important for understanding the deep crustal configuration of the earth's crust, the first step was to separate the regional component of the Bouguer gravity signal, the same was isolated from the gravity signal. While various techniques are available for the separation of the long wavelength (regional) and short wavelength (residual) components of the observed signal (Agocs, 1951 and Agarwal and Sivaji, 1992), Polynomial fitting (Lowerie,1997) is a relatively straight forward and commonly used method that allows for a judicious mix of bias-free mathematical analysis and ground geology.

Since with increasing order of the assumed curve approaches the original set of observations, for optimal fit the appropriate order polynomial has to be selected for of the $5^{\text {th }}$ order polynomial fit to the observed Bouguer gravity 
along the Traverse from T1 to T11 (along $12^{\circ}$ to $17^{\circ}$ ) in the Dharwar Craton., the $5^{\text {th }}$ order polynomial was founded to be most representative of the expected regional and was utilized to explain features of deep-seated significance as detailed in the following paragraphs

A 4-layer models was assumed for crustal configuration down to the Moho- a top layer of peninsular gneiss that forms the basement to the supra-crustal, the upper crustal layer, deeper crustal layer bounded at its lower end by the Moho. While the supra crustal within the host peninsular gneisses are broadly identified from the known geology. The corresponding densities of deep seated formations are assumed by the earlier studies (Ramadass.et.al.,2006), are $2.67 \mathrm{gm} / \mathrm{cc}, 2.72 \mathrm{gm} / \mathrm{cc}, 2.85 \mathrm{gm} / \mathrm{cc}$ and $3.3 \mathrm{gm} / \mathrm{cc}$ respectively. and used as a base to constrain to the present gravity modeling through GMSYS (2010) Software. The best fit between observed and computed anomaly profiles for the gravity data was obtained by interactively modifying the configuration of the assumed layers. The least square error between the observed and computed profiles was $1.5 \%$ for gravity.

Travers 1:-This traverse (Figure.3) runs from west to east along Latitude- $12^{\circ}$ is approximately $380 \mathrm{~km}$ in length The Regional Bouguer Gravity anomaly varies from a maximum value of $-52.05 \mathrm{mGal}$ in the western part of and a minimum value of $-92.65 \mathrm{mGal}$ in the eastern part, based on gravity and horizontal gradient maxima and minima faults are identified figure (3a) faultsF1 and one small fault $\mathrm{F} 2$ are located at the $33.58 \mathrm{~km}$ and $152.89 \mathrm{~km}$, similarly Faults F3 and F4 are traced at $293.93 \mathrm{Km}$ and $366.73 \mathrm{Km}$. The crustal section figure (3d) along this profile Peninsular thickness is varying from $8.8 \mathrm{~km}$, to $12.4 \mathrm{~km}$. Upper crustal a thickness is varying $19.74 \mathrm{~km}$ to $22.61 \mathrm{~km}$ and Deeper crustal thickness is varying $31.52 \mathrm{~km}$, to $36.9 \mathrm{~km}$. The upper and deeper crustal layers are fairly uniform in configuration. The upper crustal layer is thicker on the western side while the deeper crustal layer is thicker on the eastern side. The Moho occurs at depths between $31 \mathrm{~km}$ to $37 \mathrm{~km}$

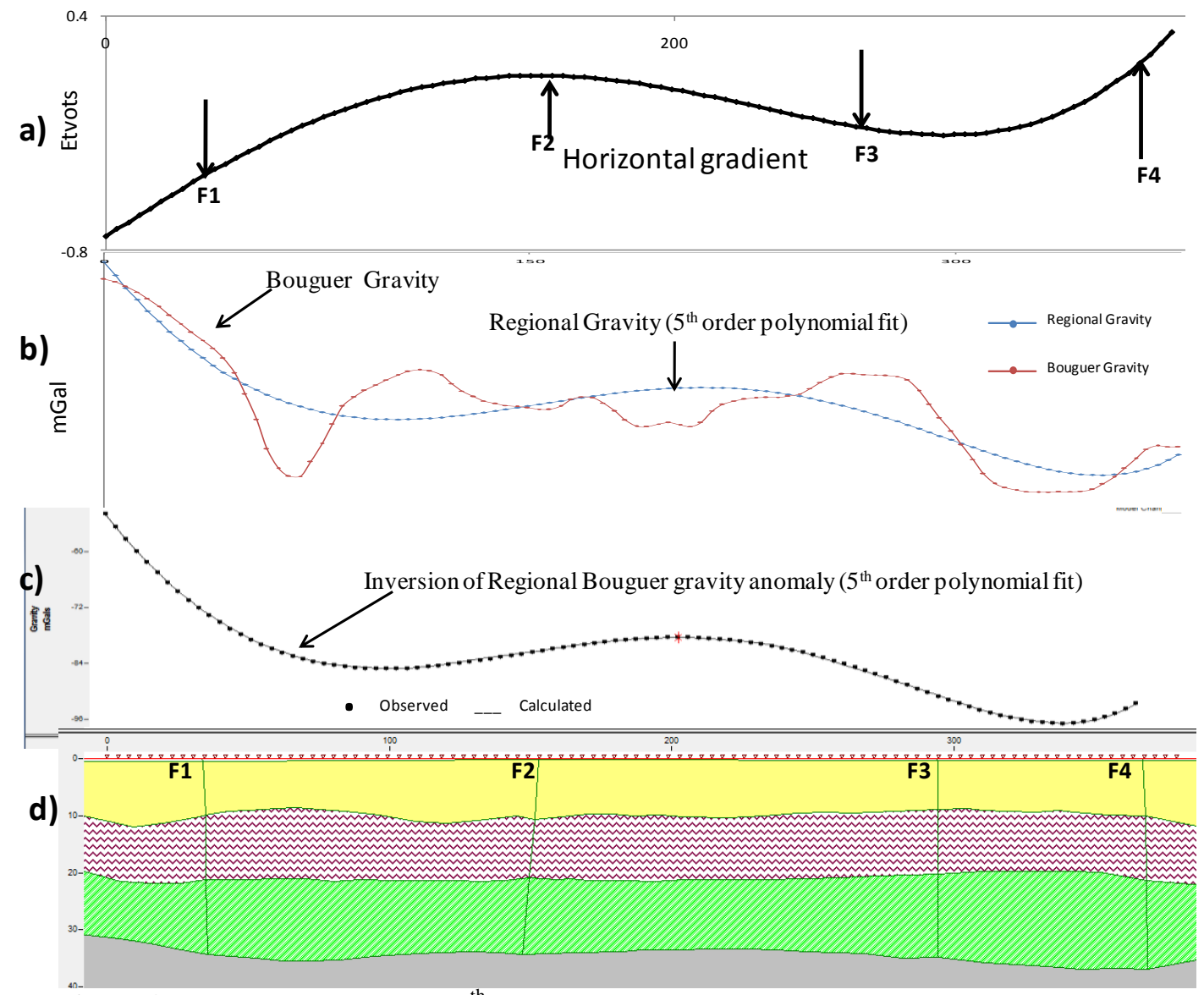

Figure 3:-(a) Horizontal gravity ( $5^{\text {th }}$ polynomial) Gradient, (b) Regional and Residual separation( $5^{\text {th }}$ order polynomial), (c) Inversion of Regional Bouguer gravity $\left(5^{\text {th }}\right.$ order polynomial) along the Traverses-T1, (d) Inferred Structural Configuration along the Traverses-T1 (Latitude- $12^{\circ}$ ) 
Travers-2: Traverse-2 which runs (Figure.4d ) runs from west to east along Latitude- $12^{\circ} .30^{\prime}$ is approximately $414 \mathrm{~km}$ in length exhibiting regional gravity figure.4(c) varies from $43.92 \mathrm{~m}$ Gal to $-92.85 \mathrm{mGals}$. The crustal section along this profile is for the major part marked by gentle undulations. The topmost layer comprising younger granites is exposed at surface almost completely, where the higher density peninsular gneissic layer, is exposed to shallow depth. As compared to the deeper layers, these layers have an irregular shape. The peninsular gneissic (P.G) have a variable thickness ranging from 0 to $10 \mathrm{~km}$.

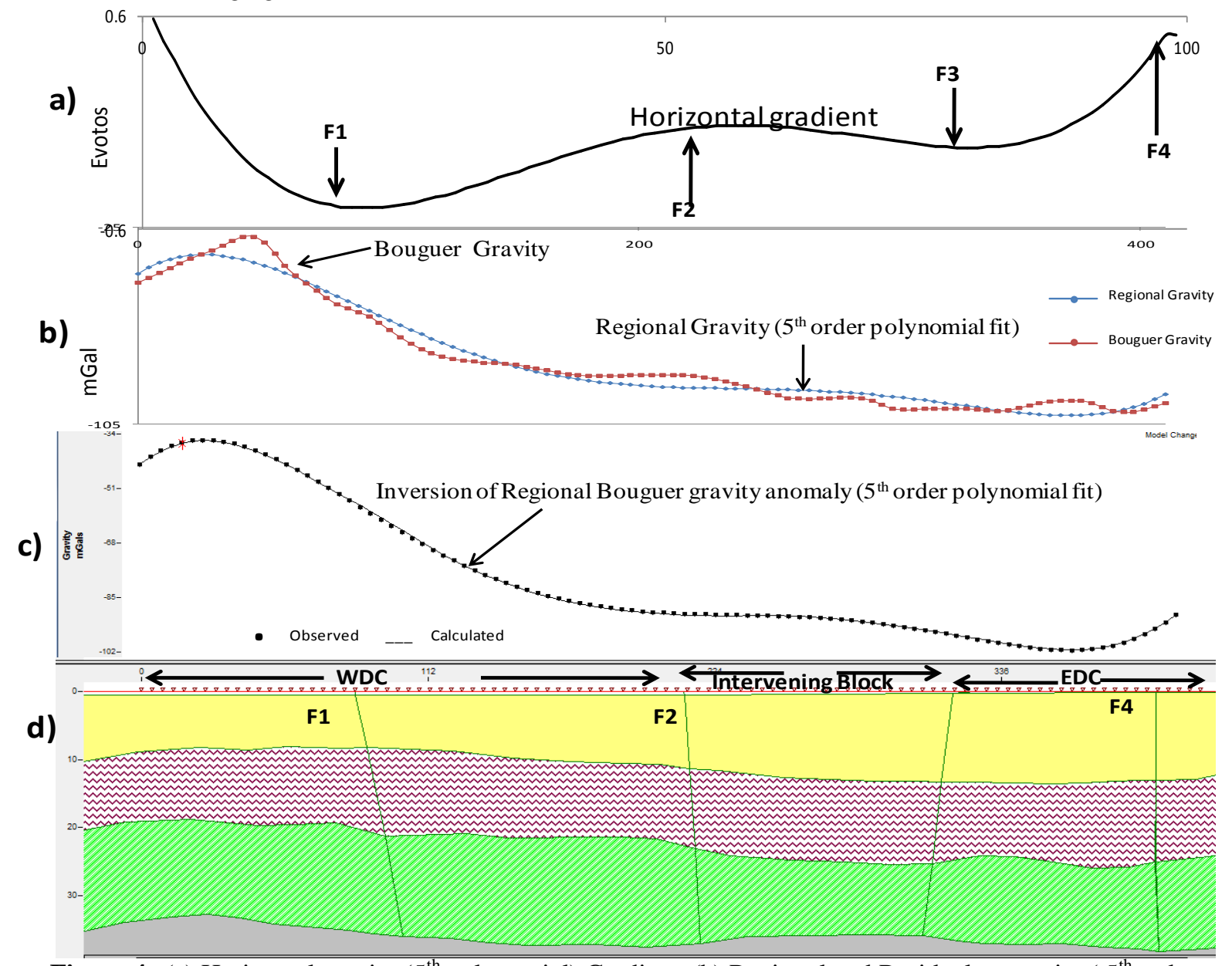

Figure 4:-(a) Horizontal gravity $\left(5^{\text {th }}\right.$ polynomial) Gradient, (b) Regional and Residual separation( $5^{\text {th }}$ order polynomial), (c) Inversion of Regional Bouguer gravity ( th $^{\text {th }}$ order polynomial) along the Traverses-T2, (d) Inferred Structural Configuration along the Traverses-T2 (Latitude-12 $30^{\prime}$ )

There are three dipping faults i.e F1,F2 and F3 is figure.4(a) located at is indicated at the $84.10 \mathrm{~km}, 318.16 \mathrm{Km}$ and $397.17 \mathrm{Km}$ which is marked by steep gradient all the underline layers which were infer from qualitative analysis (Figure. 4d ). Peninsulargneissic thickness is minimum $8.12 \mathrm{~km}$, maximum $14.44 \mathrm{~km}$, The under lying upper crustal and deeper crustal layers have gently undulating topography, with thickness ranges from 18.75-25.48 $\mathrm{km}$ and 32.71-39 $\mathrm{km}$ respectively.

Travers 3:- This traverse (Figure.5) is $424 \mathrm{~km}$, runs through the Hassan, Bangalore and near Kolar villages from west to east along Latitude- $13^{\circ}$ is approximately $424 \mathrm{~km}$ in length .From figure $(5 \mathrm{~d})$ it is seen that the Peninsular gneissic layer shows gentle undulations and greater variation in thickness than the layers the beneath. The gravity lows along the traverse are observed, might be characterized by greater thickness . 


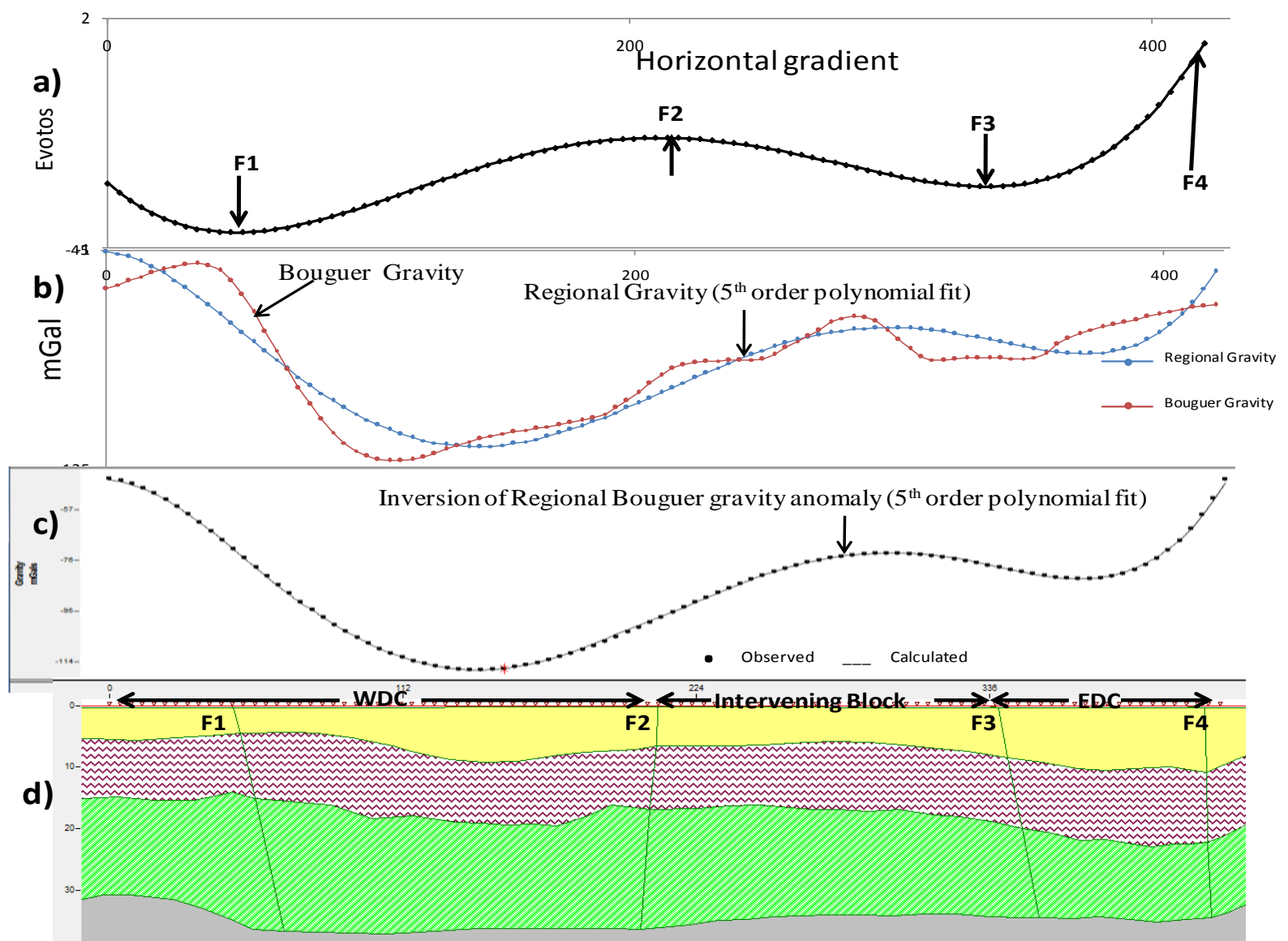

Figure 5:-(a) Horizontal gravity $\left(5^{\text {th }}\right.$ polynomial) Gradient, (b) Regional and Residual separation( $5^{\text {th }}$ order polynomial), (c) Inversion of Regional Bouguer gravity ( $5^{\text {th }}$ order polynomial) along the Traverses-T3, (d) Inferred Structural Configuration along the Traverses-T3 (Latitude-13 ${ }^{\circ}$ )

The gravity high on the profile are seen at the western side, are associated with both, thinning of the peninsular gneissic layer as well as corresponding upwarps of the relatively higher density Upper and deeper crustal layers and the Moho. There are four faults i.e F1, F2, F3 and F4 demarcated figure.5 (a) at 47.19Km, $209.33 \mathrm{Km}$, $337.85 \mathrm{~km}$ and $471.45 \mathrm{Km}$ have Peninsulargneissic thickness is varying from $4.5-10.8 \mathrm{~km}$, Upper crustal a thickness is 14.02 to $22.96 \mathrm{~km}$ and Deeper crustal thickness is $30.83-37.08 \mathrm{~km}$ respectively.

Travers 4:- This traverse (Figure.6d) runs from west to east along Latitude-1330' near North of Timkur village is approximately $429 \mathrm{~km}$ in length. The regional bouguer gravity anomaly along this figure.6(c) traverse exhibits a range of maximum value of $-60.3288 \mathrm{mGal}$ and Minimum Value $-108.034 \mathrm{~m}$.Gals. Four faults there are F1, F2, F3 and F4 figure.6(a) inferred at $62.82 \mathrm{Km}, 214.93 \mathrm{Km}, 334.02 \mathrm{Km}$ and $411.26 \mathrm{Km}$ corresponding depths is the corresponding crustual configuration is peninsulargneissic layer is figure.6(d) varies from maximum $6.33-12.37 \mathrm{~km}$, Upper crustal is 18.14 to $24.19 \mathrm{~km}$ and deeper crustal layer varying from $35.40-39.06 \mathrm{~km}$. 


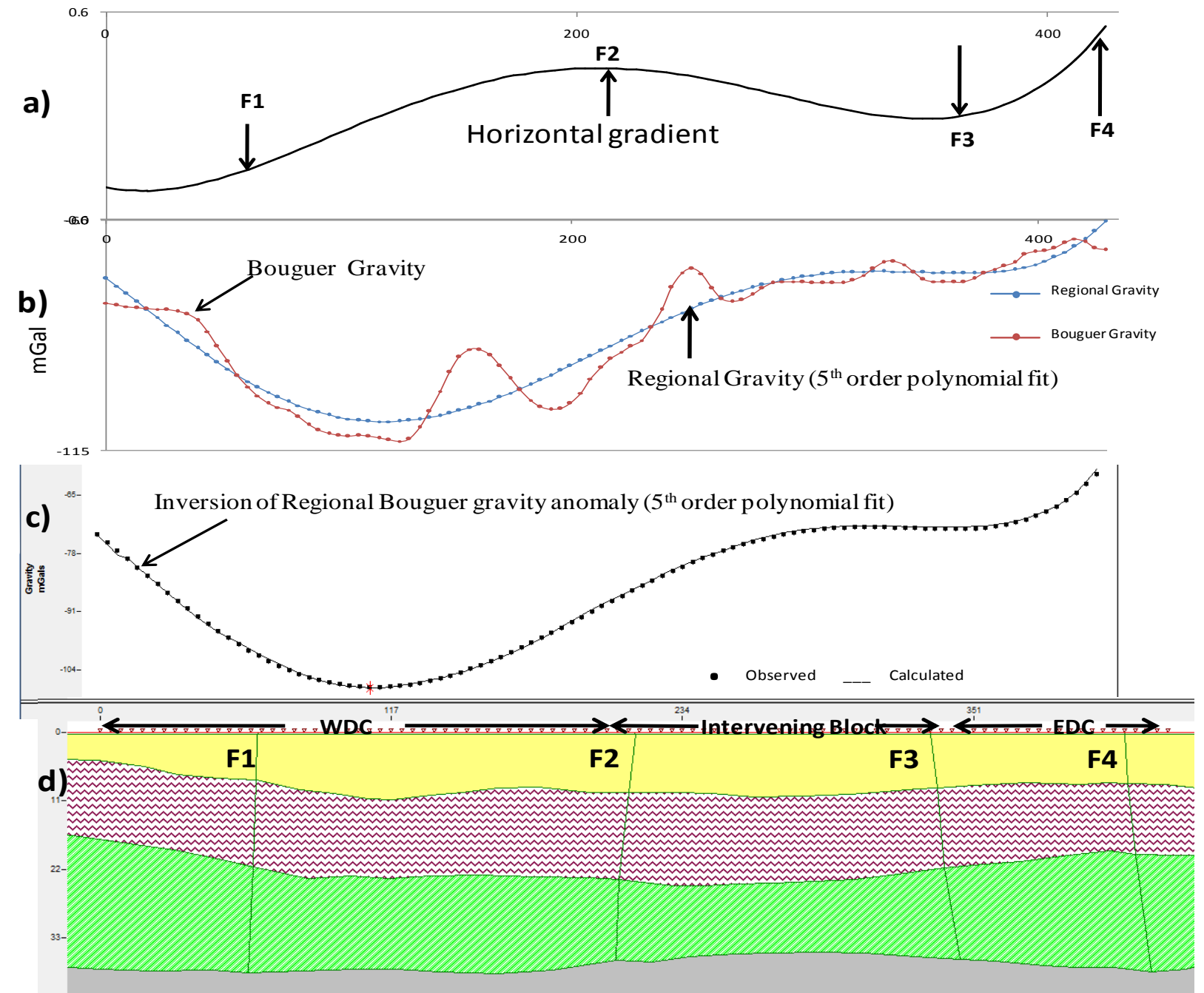

Figure 6:- (a) Horizontal gravity ( $5^{\text {th }}$ polynomial) Gradient, (b) Regional and Residual separation( $5^{\text {th }}$ order polynomial), (c) Inversion of Regional Bouguer gravity ( $5^{\text {th }}$ order polynomial) along the Traverses-T4, (d) Inferred Structural Configuration along the Traverses-T4 (Latitude-13 $30^{\prime}$ )

Travers 5:- This traverse (Figure.7d) running through the Bhatkal and north of the Simoga and Hindupur villages from west to east along Latitude- $14^{\circ}$ is approximately $424 \mathrm{~km}$ in length shows aanomaly range of maximum value of $-72.95 \mathrm{mGal}$ and Minimum Value $-103.02 \mathrm{~m}$. Gals figure.7(c) . Figure. 7(a) there are four faults traced Gradients faults F1,F2 , F3 and F4 is marked at $55.65 \mathrm{Km}, 205.40 \mathrm{Km}, 360.46 \mathrm{Km}$ and $420.60 \mathrm{Km}$ corresponding depths of faults points. While the Baba group evident between the $205.40 \mathrm{~km}$ to $360.46 \mathrm{Km}$ Figure.7(d). 


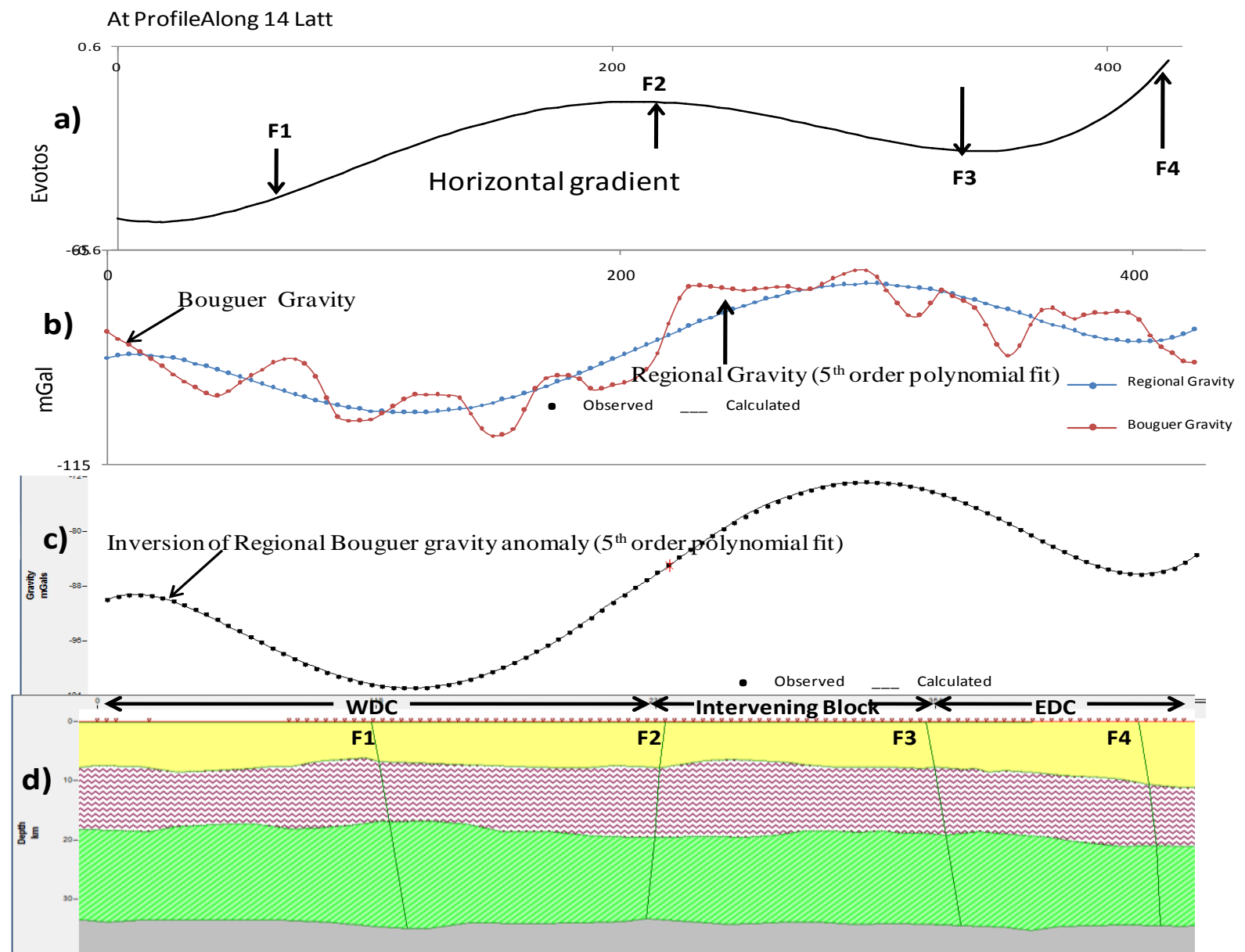

Figure 7:- (a) Horizontal gravity ( $5^{\text {th }}$ polynomial) Gradient, (b) Regional and Residual separation $\left(5^{\text {th }}\right.$ order polynomial), (c) Inversion of Regional Bouguer gravity ( $5^{\text {th }}$ order polynomial) along the Traverses-T5, (d) Inferred Structural Configuration along the Traverses-T5 (Latitude-14²)

Crustal configuration along this traverse upwelling in the moho are discernible, the up warps in the Upper crustal layer are more pronounced. The Peninsular gneissic thickness is varies from to $6.33 \mathrm{~km}-13.12 \mathrm{~km}$, Upper crustal and deeper crustal layers thickness varies between is $18.87-24.19 \mathrm{~km}$ and Deeper crustal thickness $34.92 \mathrm{~km}$ $39.60 \mathrm{~km}$.

Travers 6:- This traverse (Figure.8d) running north of Devangere and Darmavarum villages from west to east along Latitude- $14^{\circ} 30^{\prime}$ is approximately $460 \mathrm{~km}$ in length. The regional Bouguer gravity anomaly figure.8(c) along this traverse exhibits a range of maximum value of $-66.67 \mathrm{mGal}$ and Minimum Value $-84.11 \mathrm{mGals}$. There are two dipping faults i.e F2 (BN) and F3 (CG) and two small faults F1 and F4 is indicated at the $239.33 \mathrm{~km}$ and $350.55 \mathrm{~km}$ and shallow depth faults located at $115.48 \mathrm{~km}$ and $440 \mathrm{~km}$ which is marked by all the underline layers which were infer from qualitative analysis (Figure.8a ). Peninsulargneissic thickness is minimum $6.15 \mathrm{~km}$, maximum $11.32 \mathrm{~km}$, Upper crustal a thickness is minimum $16.87 \mathrm{~km}$, maximum $21.14 \mathrm{~km}$ and Deeper crustal thickness is minimum $34.53 \mathrm{~km}$, maximum $36.83 \mathrm{~km}$ Figure.8(d). 


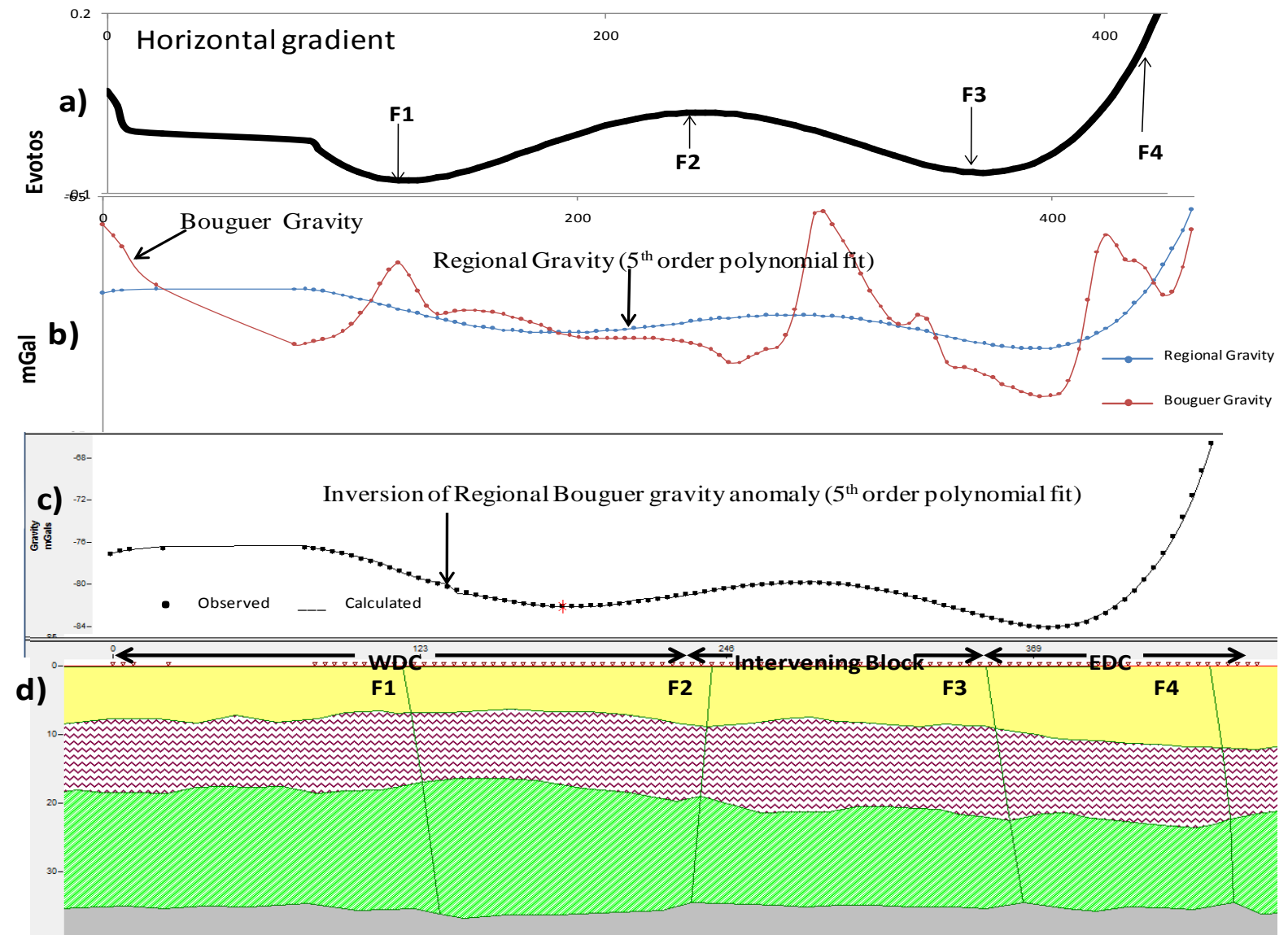

Figure 8:-(a) Horizontal gravity ( $5^{\text {th }}$ polynomial) Gradient, (b) Regional and Residual separation $\left(5^{\text {th }}\right.$ order polynomial), (c) Inversion of Regional Bouguer gravity ( $5^{\text {th }}$ order polynomial) along the Traverses-T6, (d) Inferred Structural Configuration along the Traverses-T6 (Latitude-14²0')

Travers 7:- This traverse (Figure.9d) runs from west to east along Latitude- $15^{\circ}$ is approximately $513 \mathrm{~km}$ in length the crustal section along this profile is for the major part marked by gentle undulations. The regional bouguer gravity anomaly figure. 9 (c) along this traverse exhibits a range of maximum value of $-34.57 \mathrm{mGal}$ and Minimum Value 91.37 m.Gals. There are three dipping faults i.e F1, F2 (BN) and F3 (CG) are figure. located at the corresponding depths at $20.25 \mathrm{Km}, 198.89 \mathrm{Km}, 361.03 \mathrm{Km}$ and one small fault $490 \mathrm{~km}$ shallow depth fault which is marked by all the underline layers which were infer from qualitative analysis (Figure. 9a ). 


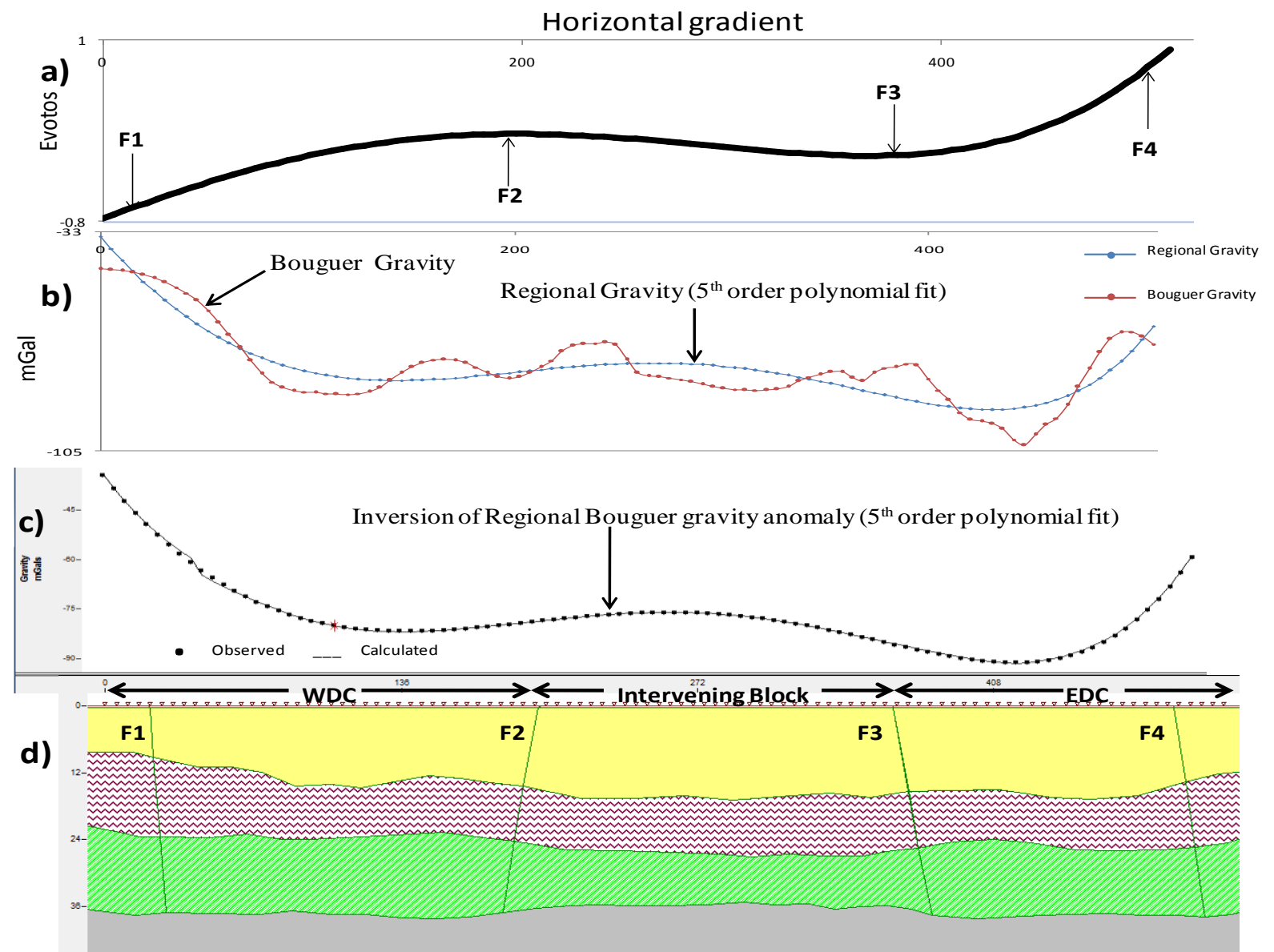

Figure 9:- (a) Horizontal gravity ( $5^{\text {th }}$ polynomial) Gradient, (b) Regional and Residual separation( $5^{\text {th }}$ order polynomial), (c) Inversion of Regional Bouguer gravity ( $5^{\text {th }}$ order polynomial) along the Traverses-T7, (d) Inferred Structural Configuration along the Traverses-T7 (Latitude- $15^{\circ}$ )

Peninsulargneissic thickness is minimum $8.29 \mathrm{~km}$, maximum $15.12 \mathrm{~km}$, Upper crustal a thickness is minimum 22.41 $\mathrm{km}$, maximum $25.41 \mathrm{~km}$ and Deeper crustal thickness is minimum $35.12 \mathrm{~km}$, maximum $38.23 \mathrm{~km}$ figure.9d.

Travers-8: This traverse (Figure.10 d) running near Panjim, Hubli, Gadag and Londa villages from west to east along Latitude- $15^{\circ} 30^{\prime}$ is approximately $528 \mathrm{~km}$ in length is north to the travers- 7 . The regional bouguer gravity anomaly along this traverse exhibits a range of maximum value of $-27.97 \mathrm{mGal}$ and Minimum Value -93.72 m.Gals figure.10(c). There are three dipping faults i.e F1, F2 (BN) and F3 (CG) located figure.10 (a) at the 38.70 $\mathrm{km}, 198 \mathrm{~km}$ and $399.38 \mathrm{Km}$. Peninsular gneissic layer thickness is minimum $6.17 \mathrm{~km}$, maximum $8.34 \mathrm{~km}$, Upper crustal a thickness is minimum $15.49 \mathrm{~km}$, maximum $21.38 \mathrm{~km}$ and Deeper crustal thickness is minimum $35.12 \mathrm{~km}$, maximum $38.59 \mathrm{~km}$ figure. $10 \mathrm{~d}$. 

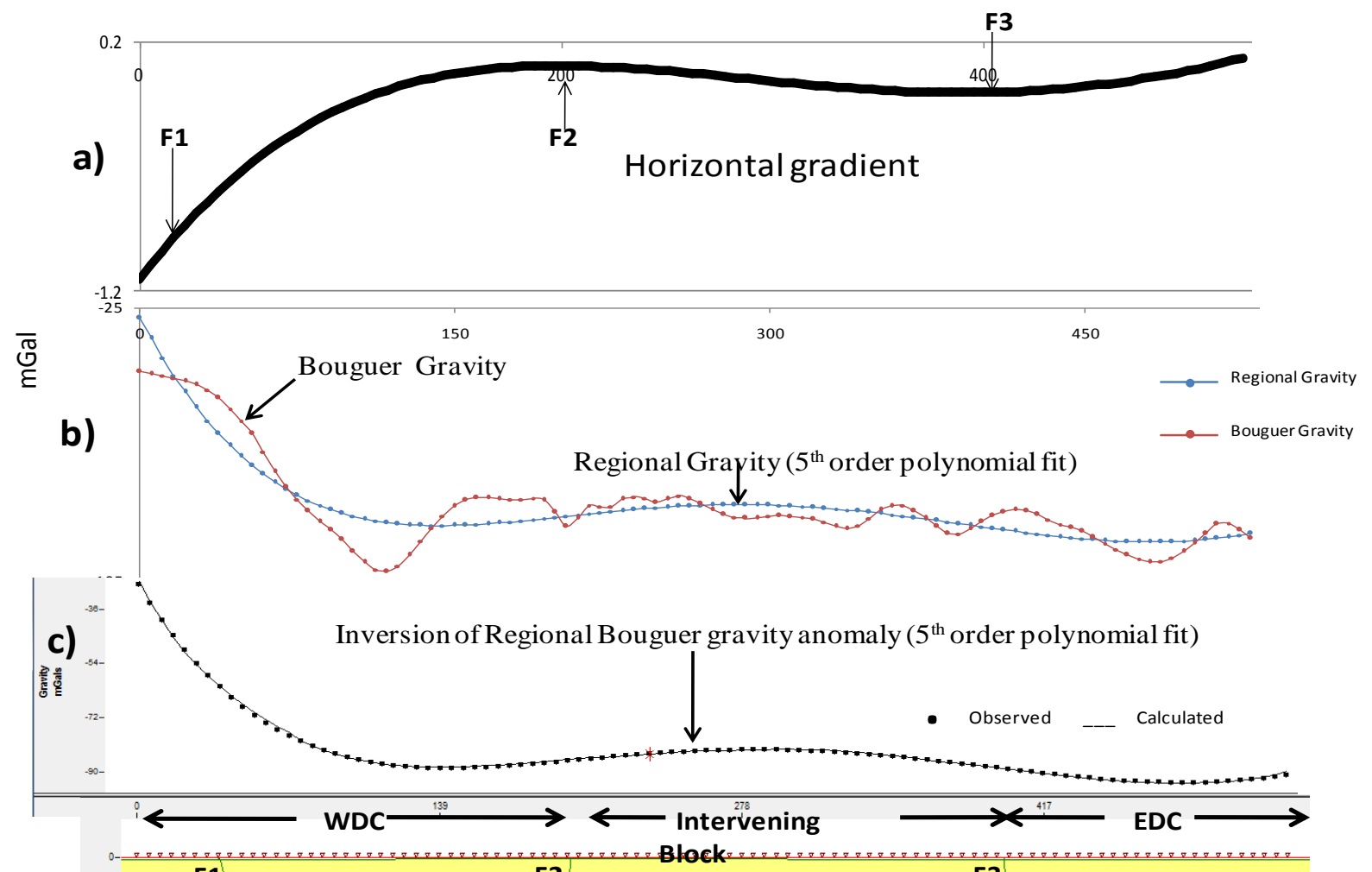

d)

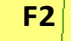

F3

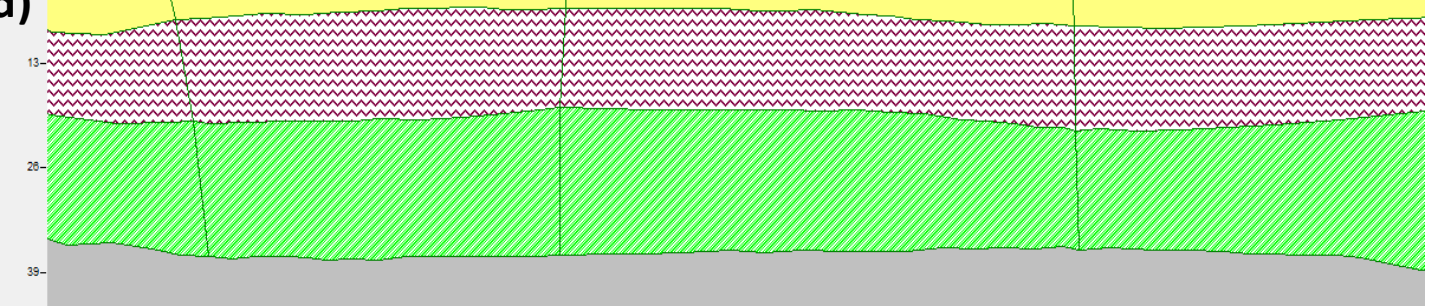

Figure 10:- (a) Horizontal gravity $\left(5^{\text {th }}\right.$ polynomial) Gradient, (b) Regional and Residual separation $\left(5^{\text {th }}\right.$ order polynomial), (c) Inversion of Regional Bouguer gravity ( $5^{\text {th }}$ order polynomial) along the Traverses-T8, (d) Inferred Structural Configuration along the Traverses-T8 (Latitude-15³0')

Travers 9:- This traverse (Figure.11 d) running near to Belgum from west to east along Latitude- $16^{\circ}$ is approximately $554 \mathrm{~km}$ in length. The regional Bouguer gravity anomaly figure.11(c) along this traverse exhibits a range of maximum value of $-48.29 \mathrm{mGal}$ and Minimum Value $-94.38 \mathrm{~m}$.Gals. 

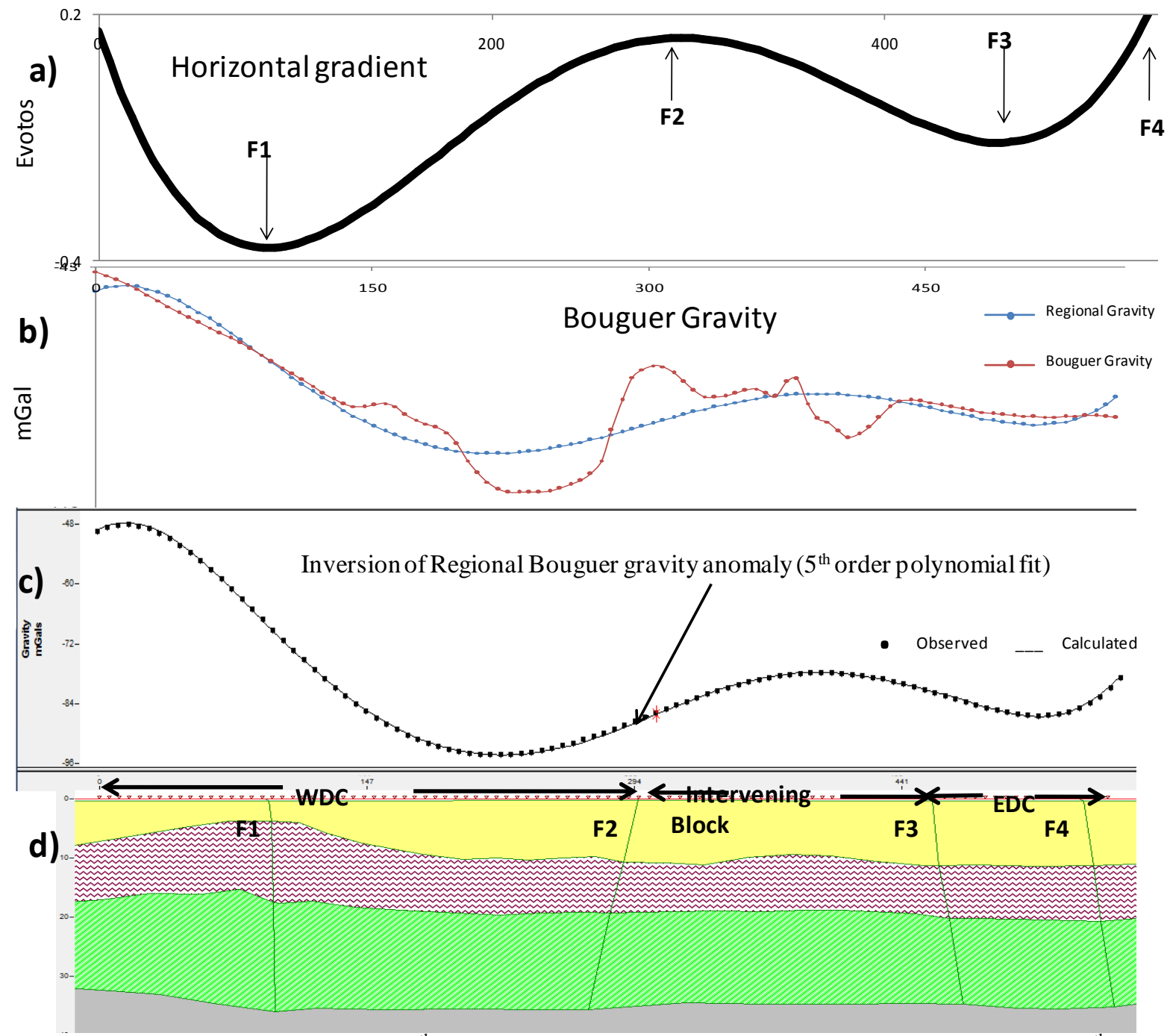

Figure 11:- (a) Horizontal gravity $\left(5^{\text {th }}\right.$ polynomial) Gradient, (b) Regional and Residual separation $\left(5^{\text {th }}\right.$ order polynomial), (c) Inversion of Regional Bouguer gravity ( $5^{\text {th }}$ order polynomial) along the Traverses-T9, (d) Inferred Structural Configuration along the Traverses-T9 (Latitude-16²)

There are two dipping faults i.e F2(BN) and F3 (CG) and two local faults F1 and F4 and there corresponding located at $295.88 \mathrm{~km}$ and $457.41 \mathrm{~km}$ and local faults at $93.56 \mathrm{~km}$ and $541.37 \mathrm{~km}$, which is marked by all the underline layers which were infer from qualitative analysis (Figure. $11 \mathrm{a}$ ). Peninsular gneissic layer thickness is minimum $3.24 \mathrm{~km}$, maximum $11.47 \mathrm{~km}$, Upper crustal a thickness is minimum $15.80 \mathrm{~km}$, maximum $20.49 \mathrm{~km}$ and Deeper crustal thickness is minimum $32.49 \mathrm{~km}$, maximum $35.97 \mathrm{~km}$ Figure. $11 \mathrm{~d}$.

Travers-10: This traverse (Figure.12 d) running near Talikota from west to east along Latitude-16 $30^{\prime}$ is approximately $570 \mathrm{~km}$ in length. The regional Bouguer gravity anomaly figure.12 (c) along this traverse exhibits a range of maximum value of $-35.65 \mathrm{mGaland}$ Minimum Value $-90.75 \mathrm{~m}$.Gals. There are one dipping fault i.e F2(BN) is indicated at the $251 \mathrm{~km}$ and two local faults F1 and F3 local faults at $45.15 \mathrm{~km}$ and $535.60 \mathrm{~km}$ figure.12(a). Peninsular gneissic layer thickness is minimum $4.43 \mathrm{~km}$, maximum $9.77 \mathrm{~km}$, Upper crustal a thickness is minimum $17.16 \mathrm{~km}$, maximum $22.49 \mathrm{~km}$ and Deeper crustal thickness is minimum $33.60 \mathrm{~km}$, maximum 38.35 $\mathrm{km}$ figure.12d. 


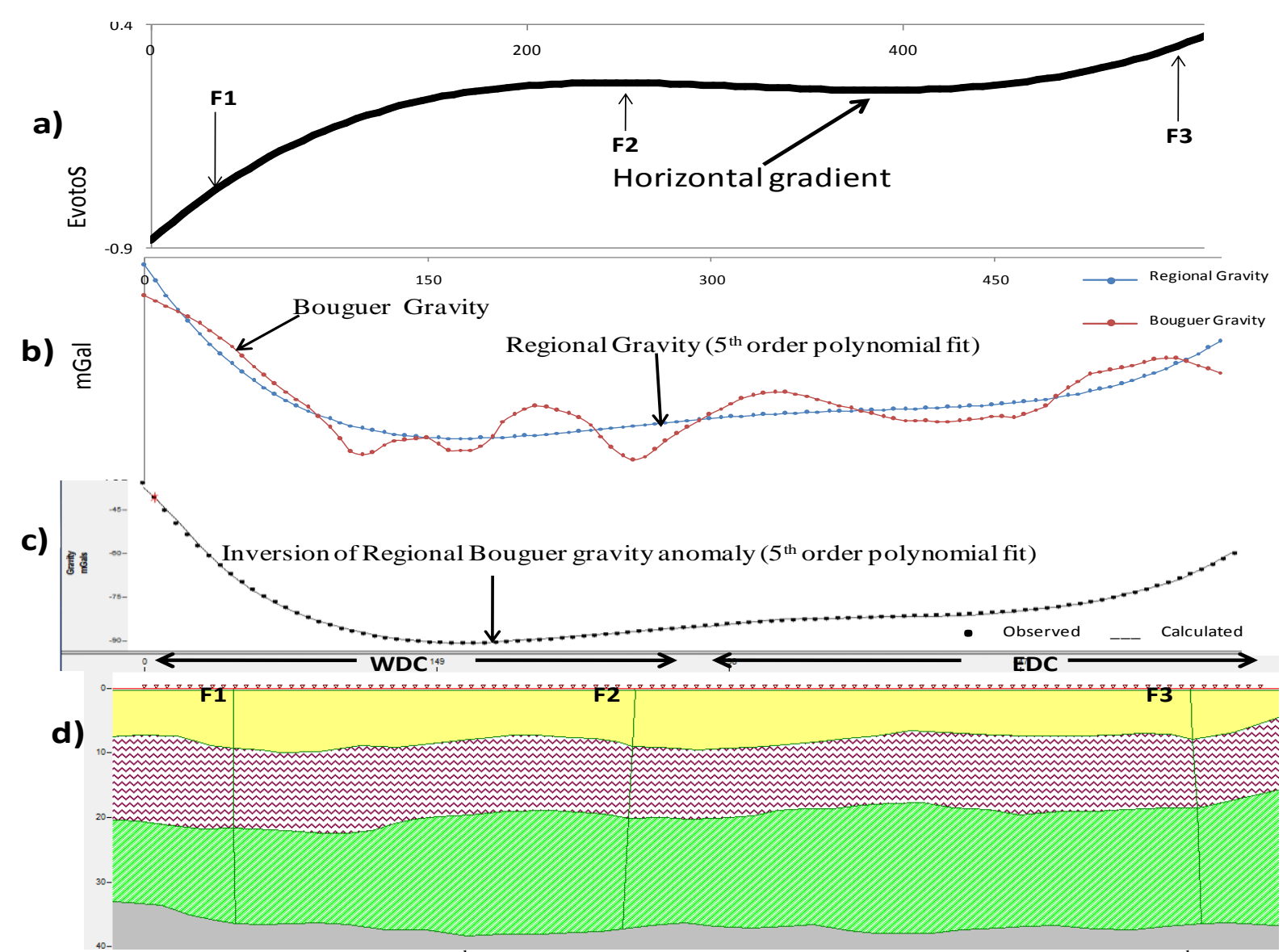

Figure 12:- (a) Horizontal gravity $\left(5^{\text {th }}\right.$ polynomial) Gradient, (b) Regional and Residual separation $\left(5^{\text {th }}\right.$ order polynomial), (c) Inversion of Regional Bouguer gravity ( $5^{\text {th }}$ order polynomial) along the Traverses-T10, (d) Inferred Structural Configuration along the Traverses-T10 (Latitude-16 $30^{\prime}$ )

Travers 11:- This traverse (Figure.13.d) runnig through the Ratnagiri from west to east along Latitude- $17^{\circ}$ is approximately $583 \mathrm{~km}$ in length. The regional bouguer gravity anomaly figure.13(c) along this traverse exhibits a range of maximum value of $-8.92 \mathrm{mGal}$ and Minimum Value $-98.46 \mathrm{~m}$. Gals. 

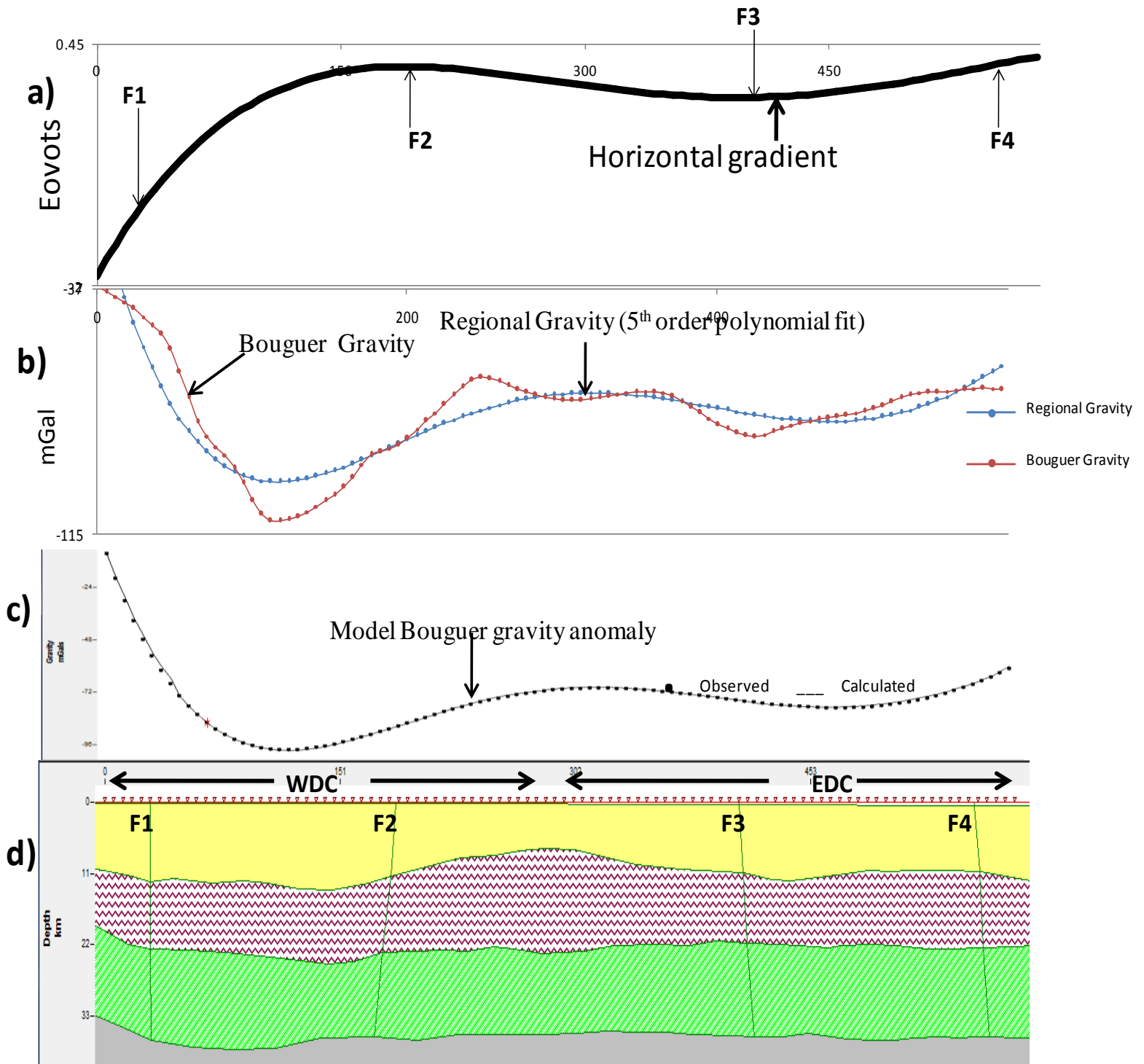

Figure 13:- (a) Horizontal gravity ( $5^{\text {th }}$ polynomial) Gradient, (b) Regional and Residual separation( $5^{\text {th }}$ order polynomial), (c) Inversion of Residual Bouguer gravity $\left(5^{\text {th }}\right.$ order polynomial) along the Traverses-T3, (d) Inferred Structural Configuration along the Traverses-T11 (Latitude-17²)

There are four dipping faults i.e F1, F2, F3 and F4 is figure.13(a) indicated at the $28.55 \mathrm{~km}, 186.84 \mathrm{~km}, 406.24 \mathrm{~km}$ and $57.13 \mathrm{Km}$. Peninsular gneissic layer thickness is minimum $3.06 \mathrm{~km}$, maximum $11.79 \mathrm{~km}$, Upper crustal a thickness is minimum $17.16 \mathrm{~km}$, maximum $21.25 \mathrm{~km}$ and Deeper crustal thickness is minimum $34.47 \mathrm{~km}$, maximum $37.68 \mathrm{~km}$ figure.13(d). Thus obtained results are tabulated in Table.1.

The deep crustal configuration obtained from modeling of regional Bouguer gravity ( $5^{\text {th }}$ polynomial) along the traverse T1 to T11 presented in Fig.14., together to view the two dimensional representation for understanding the nature of the tectonics of the Dharwrcraton. It is evident from this the variation in layer thickness is greatest for the uppermost peninsular gneissic layer that ranges in thickness from $0 \mathrm{~km}$ at the western end to nearly $26 \mathrm{~km}$ near Dharwar. In contrast, the upper and deeper crustal layers are comparatively more uniform in thickness, with the top and bottom surfaces of the layers varying between 2-7 km and 15-32 km respectively. Upwarps in the Moho are associated with a marked decrease in the thickness of the peninsular gneissic layer while the maximum thickness of the layer is correspondingly associated with a downwarp in the Moho. 
The maximum gradients (upwarps and downwarps) in the configuration of the upper and deeper crustal layers that have a corresponding expression in the Moho are attributed to faults of crustal dimensions. Thus, four deep-seated faults (Fig. 3) extending down to the Moho (Ramadass et al., 2006; Himabindu and Ramadass, 2003; Himabindu and Ramadass, 2004).are inferred from horizontal gradient analysis. The fault $\mathrm{F}_{\mathrm{I}}$ at stations (33.58-T1, 84.10-T2, 47.19-T3, 62.82-T4, 55.65-T5, 115.48-T6, 20.25-T7, 38.70-T8, 93.56-T9, 45.15-T10 \& 28.55-T11), western part of the study region and separates the Upper Dharwar sediments from the younger granites in the region. The second fault $\mathrm{F}_{\text {II }}$ at stations (152.89-T1, 318.16-T2, 209.33-T3, 214.93-T4, 205.40-T5, 239.33-T6, 198.89-T7, 198.29 -T8, 295.88-T9, 251.94 -T10 \& 186.84-T11) corresponds to the Bababudan - Nallur shear. The third fault $\mathrm{F}_{\mathrm{III}}$ at stations (293.93 -T1, 397.17 -T2, 337.85 -T3, 334.02 -T4, 360.46 -T5, 350.55 -T6, 361.03 -T7, 399.38 -T8, 457.41 -T9, 535.60-T10 \& 406.24 -T11) is along the western margin of the Closepet batholith and the last $\mathrm{F}_{\mathrm{IV}}$ at stations ( 366.73-T1-T2, 417.45-T3, 411.26-T4, 420.60-T5, 440.04-T6, 490.14-T7, 541.37-T9 \& 557.13-T11 ) lies east of the younger granite batholith that encompasses the eastern part. Faults $F_{I}$ and $F_{I I I}$ are parallel to each other. Similarly, faults $F_{I I}$ and $F_{I V}$ are also nearly parallel to each other, and dip to the west. These faults are associated with throws ranging from 3 to $6 \mathrm{~km}$. Thus, broadly, three tectonic blocks are evident in the craton: the western $\mathbf{W}$ (west of fault $\mathrm{F}_{\mathrm{II}}$ ), the intervening $\mathbf{I}$ (between faults $\mathrm{F}_{\mathrm{II}}$ and $\mathrm{F}_{\mathrm{III}}$ ) and the eastern $\mathbf{E}$ (east of $\mathrm{F}_{\mathrm{III}}$ ) blocks.

Table 1:- Crustal configuration of the Dharwar Craton.

\begin{tabular}{|c|c|c|c|c|c|c|}
\hline \multirow[t]{2}{*}{$\begin{array}{l}\text { Traverses No } \\
\text { ( Degrees) }\end{array}$} & \multirow[t]{2}{*}{ Depth to top of layer } & \multicolumn{2}{|c|}{$\begin{array}{l}\text { Western Dharwar Block } \\
\text { (WDB) } \\
\text { Depth in Km }\end{array}$} & \multirow{2}{*}{\begin{tabular}{|l|} 
Intervening \\
Block(IB) \\
Depth in Km \\
$\mathrm{F}_{\mathrm{II}}-\mathrm{F}_{\mathrm{III}}$ \\
\end{tabular}} & \multicolumn{2}{|c|}{$\begin{array}{l}\text { Eastern Dharwar Block } \\
\text { (EDB) } \\
\text { Depth in } \mathrm{Km}\end{array}$} \\
\hline & & West of $F_{I}$ & $\mathrm{~F}_{\mathrm{I}}-\mathrm{F}_{\mathrm{II}}$ & & $\mathrm{F}_{\mathrm{III}}-\mathrm{F}_{\mathrm{IV}}$ & East of $F_{I V}$ \\
\hline $\begin{array}{l}\text { Traverses- } 1 \\
\text { Lattitude }-12^{\circ}\end{array}$ & $\begin{array}{l}\text { Fault Location } \\
\text { Peninsular Gneissis } \\
\text { Upper Crustal Layer } \\
\begin{array}{l}\text { Deeper } \\
\text { Layer(Moho) }\end{array} \\
\begin{array}{l}\text { Average } \\
\text { thickness }\end{array}\end{array}$ & $\begin{array}{l}33.58 \text { (FI) } \\
9.80-11.88 \\
21.28-21.93 \\
\\
31.52-34.32 \\
32.98\end{array}$ & $\begin{array}{l}152.89 \\
\text { (FII) } \\
8.50- \\
11.32 \\
20.93- \\
21.58 \\
\\
33.87- \\
35.55 \\
34.7125\end{array}$ & $\begin{array}{l}293.93 \text { (FIII) } \\
8.82-10.62 \\
20.24-21.46 \\
33.35-35.07 \\
34.21\end{array}$ & $\begin{array}{l}366.73 \\
\text { (FIV ) } \\
8.80- \\
10.06 \\
19.74- \\
21.38 \\
\\
34.89- \\
36.90 \\
35.89\end{array}$ & $\begin{array}{l}10.06- \\
12.35 \\
21.38- \\
22.61 \\
34.57- \\
36.90 \\
35.73\end{array}$ \\
\hline $\begin{array}{l}\text { Traverses-2 } \\
\text { Lattitude } \\
12^{\circ} 30\end{array}$ & \begin{tabular}{l}
\multicolumn{2}{l}{ Fault Location } \\
Peninsular Gneissis \\
Upper Crustal Layer \\
$\begin{array}{l}\text { Deeper } \\
\text { Layer(Moho) }\end{array}$ \\
$\begin{array}{l}\text { Average } \\
\text { thickness }\end{array}$
\end{tabular} & $\begin{array}{l}84.10 \text { (FI) } \\
8.12-8.58 \\
18.75-21- \\
61 \\
\\
32.71-36.03 \\
34.37\end{array}$ & $\begin{array}{l}318.16 \\
\text { (FII) } \\
8.53- \\
11.40 \\
20.80- \\
23.09 \\
\\
36.03- \\
37.49 \\
36.76\end{array}$ & $\begin{array}{l}397.17 \text { ( FIII) } \\
11.40-14.44 \\
23.09-25.48 \\
35.76-35.95 \\
35.86\end{array}$ & $\begin{array}{l}212.63(\mathrm{FIV}) \\
11.98- \\
13.61 \\
23.94- \\
25.33 \\
\\
35.84- \\
38.20 \\
37\end{array}$ & $\begin{array}{l}10.11- \\
11.98 \\
23-24.26 \\
38.20- \\
38.77 \\
38\end{array}$ \\
\hline $\begin{array}{l}\text { Traverses-3 } \\
\text { Lattitude }-13^{\circ}\end{array}$ & $\begin{array}{l}\text { Fault Location } \\
\text { Peninsular Gneissis } \\
\text { Upper Crustal Layer } \\
\begin{array}{l}\text { Deeper } \\
\text { Layer(Moho) Crustal } \\
\text { Average } \\
\text { thickness }\end{array}\end{array}$ & $\begin{array}{l}47.19 \text { (FI) } \\
4.50-5.64 \\
14.02-15.44 \\
30.83-36.65 \\
33.74\end{array}$ & $\begin{array}{l}209.33 \\
\text { (FII) } \\
4.50- \\
7.26 \\
15.12- \\
19.52 \\
\\
36.15- \\
37.08 \\
36.62 \\
\end{array}$ & $\begin{array}{l}337.85 \text { (FIII) } \\
5.86-8.47 \\
16.13-19.98 \\
\\
33.81-35.56 \\
34.67\end{array}$ & $\begin{array}{l}417.45 \\
\text { (FIV) } \\
8.47- \\
10.77 \\
19.99- \\
22.96 \\
\\
34.29- \\
35.25 \\
34.77 \\
\end{array}$ & $\begin{array}{l}8.62-10.77 \\
21.27- \\
22.14 \\
\\
31.82- \\
34.39 \\
33.11\end{array}$ \\
\hline $\begin{array}{l}\text { Traverses-4 } \\
\text { Lattitude } \\
13^{\circ} 30\end{array}$ & $\begin{array}{l}\text { Fault Location } \\
\text { Peninsular Gneissis } \\
\text { Upper Crustal Layer } \\
\text { Deeper } \quad \text { Crustal }\end{array}$ & $\begin{array}{l}62.82(\mathrm{FI}) \\
6.33-8.22 \\
18.14-21.56\end{array}$ & $\begin{array}{l}214.93 \\
\text { (FII) } \\
7.64- \\
10.82\end{array}$ & $\begin{array}{l}334.02 \text { FIII } \\
8.18-12.37 \\
18.80-24.19\end{array}$ & $\begin{array}{l}411.26 \\
\text { (FIV) } \\
7.35-8.18 \\
18.76-\end{array}$ & $\begin{array}{l}7.95-8.09 \\
19.84- \\
20.47\end{array}$ \\
\hline
\end{tabular}




\begin{tabular}{|c|c|c|c|c|c|c|}
\hline & $\begin{array}{l}\text { Layer(Moho) } \\
\text { Average } \\
\text { thickness }\end{array}$ & $\begin{array}{l}38.03-38.57 \\
38.3\end{array}$ & $\begin{array}{l}21.15- \\
24.10 \\
\\
37.68- \\
39.06 \\
38.37 \\
\end{array}$ & $\begin{array}{l}35.40-36 \\
35.7\end{array}$ & $\begin{array}{l}19.29 \\
36.39- \\
37.62 \\
37.01\end{array}$ & $\begin{array}{l}36.40- \\
38.35 \\
37.34\end{array}$ \\
\hline $\begin{array}{l}\text { Traverses-5 } \\
\text { Lattitude- } 14^{\circ}\end{array}$ & \begin{tabular}{l}
\multicolumn{2}{l}{ Fault Location } \\
Peninsular Gneissis \\
Upper Crustal Layer \\
$\begin{array}{l}\text { Deeper } \\
\text { Layer(Moho) }\end{array}$ \\
$\begin{array}{l}\text { Average } \\
\text { thickness }\end{array}$
\end{tabular} & $\begin{array}{l}55.65 \text { (FI) } \\
6.11-8.22 \\
18.88-20.10 \\
36.29-38.12 \\
37.21\end{array}$ & $\begin{array}{l}205.40 \\
\text { (FII) } \\
6.11- \\
9.48 \\
18.87- \\
21.49 \\
37.36- \\
39.60 \\
38.48\end{array}$ & $\begin{array}{l}360.46 \text { (FIII) } \\
6.97-12.04 \\
20.80-23.93 \\
34.92-36.08 \\
35.5\end{array}$ & $\begin{array}{l}420.60 \\
\text { (FIV) } \\
11.17- \\
13.12 \\
23.18- \\
24.94 \\
34.92- \\
37.15 \\
36.04\end{array}$ & $\begin{array}{l}8.95-11.17 \\
23.79- \\
24.94 \\
37.15- \\
37.69 \\
37.42\end{array}$ \\
\hline $\begin{array}{l}\text { Traverses-6 } \\
\text { Lattitude } \\
14^{\circ} 30\end{array}$ & $\begin{array}{l}\text { Fault Location } \\
\text { Peninsular Gneissis } \\
\text { Upper Crustal Layer } \\
\begin{array}{l}\text { Deeper } \\
\text { Layer(Moho) Crustal } \\
\text { Average } \\
\text { thickness }\end{array}\end{array}$ & $\begin{array}{l}115.48 \text { (FI) } \\
6.15-8.51 \\
16.89-18.40 \\
\\
34.94-36.17 \\
35.56\end{array}$ & $\begin{array}{l}239.33 \\
\text { (FII) } \\
6.76- \\
7.81 \\
16.87- \\
19.60 \\
\\
34.54- \\
36.83 \\
35.69\end{array}$ & $\begin{array}{l}350.55 \text { (FIII) } \\
6.44-7.99 \\
18.81-19.59 \\
\\
34.53-35.08 \\
34.81\end{array}$ & $\begin{array}{l}440.04 \\
\text { (FIV ) } \\
7.76- \\
10.69 \\
18.67- \\
21.08 \\
\\
34.53- \\
35.86 \\
35.2\end{array}$ & $\begin{array}{l}10.69- \\
11.32 \\
20.95- \\
21.14 \\
34.55- \\
36.21 \\
35.38\end{array}$ \\
\hline $\begin{array}{l}\text { Traverses-7 } \\
\text { Lattitude } \\
15^{\circ}\end{array}$ & $\begin{array}{l}\text { Fault Location } \\
\text { Peninsular Gneissis } \\
\text { Upper Crustal Layer } \\
\begin{array}{l}\text { Deeper } \\
\text { Layer(Moho) Crustal } \\
\text { Average } \\
\text { thickness }\end{array}\end{array}$ & $\begin{array}{l}20.25(\mathrm{FI}) \\
8.29-9.30 \\
22.41-23.51 \\
37.10-37.59 \\
37.35\end{array}$ & $\begin{array}{l}198.89 \\
\text { (FII) } \\
9.31- \\
14.46 \\
23.02- \\
24.89 \\
\\
37.10- \\
38.18 \\
\\
37.64\end{array}$ & $\begin{array}{l}361.03 \text { (FIII) } \\
13.09-14.46 \\
23.59-25.57 \\
35.12-36.42 \\
35.81\end{array}$ & $\begin{array}{l}490.14 \\
\text { (FIV) } \\
13.84- \\
15.12 \\
25.41- \\
26.51 \\
\\
37.24- \\
38.23 \\
\\
37.74 \\
\end{array}$ & $\begin{array}{l}11.17- \\
13.62 \\
24.59- \\
25.41 \\
\\
36.37- \\
37.87 \\
37.12\end{array}$ \\
\hline $\begin{array}{l}\text { Traverses-8 } \\
\text { Lattitude } \quad- \\
15^{\circ} 30\end{array}$ & $\begin{array}{l}\text { Fault Location } \\
\text { Peninsular Gneissis } \\
\text { Upper Crustal Layer } \\
\begin{array}{l}\text { Deeper } \\
\text { Layer(Moho) Crustal } \\
\text { Average } \\
\text { thickness }\end{array}\end{array}$ & $\begin{array}{l}38.70(\mathrm{FI} \\
7.65-9.56 \\
20.26-20.49 \\
35.31-36.97 \\
36.14\end{array}$ & $\begin{array}{l}198.29 \\
\text { (FII) } \\
6.17- \\
8.34 \\
18.52- \\
20.53 \\
36.97- \\
37.38 \\
37.18 \\
\end{array}$ & $\begin{array}{l}399.38(\text { FIII ) } \\
6.17-8.34 \\
18.73-21.38 \\
35.75-36.88 \\
36.32\end{array}$ & $\begin{array}{l}\text { (East of } \\
\text { FIII) } \\
8.34-8.61 \\
15.49- \\
21.38 \\
35.79- \\
38.59 \\
37.18\end{array}$ & $\begin{array}{l}\ldots \ldots \\
\cdots \cdots \\
\cdots \cdots\end{array}$ \\
\hline $\begin{array}{l}\text { Traverses-9 } \\
\text { Lattitude }-16^{\circ}\end{array}$ & $\begin{array}{l}\text { Fault Location } \\
\text { Peninsular Gneissis } \\
\text { Upper Crustal Layer } \\
\text { Deeper } \quad \text { Crustal } \\
\begin{array}{l}\text { Layer(Moho) } \\
\text { Average } \\
\text { thickness }\end{array}\end{array}$ & $\begin{array}{l}33.56 \text { (FI) } \\
3.72-6.20 \\
15.80-17.52 \\
32.49-35.96 \\
34.23\end{array}$ & $\begin{array}{l}295.88 \\
\text { (FII } \\
3.72- \\
10.66 \\
17.52- \\
20.24 \\
\\
35.60- \\
35.97 \\
\\
35.78\end{array}$ & $\begin{array}{l}457.41(\mathrm{FIII}) \\
9.27-11.26 \\
18.74-20.22 \\
34.51-35.63 \\
35\end{array}$ & $\begin{array}{l}541.37 \\
\text { (FIV) } \\
10.88- \\
11.26 \\
20.00- \\
20.66 \\
\\
34.71- \\
35.48 \\
\\
35.09\end{array}$ & $\begin{array}{l}11.22- \\
11.47 \\
20.49- \\
20.66 \\
\\
33.35- \\
35.18 \\
34.27\end{array}$ \\
\hline
\end{tabular}




\begin{tabular}{|c|c|c|c|c|c|c|}
\hline $\begin{array}{l}\text { Traverses-10 } \\
\text { Lattitude - } \\
16^{\circ} 30\end{array}$ & $\begin{array}{l}\text { Fault Location } \\
\text { Peninsular Gneissis } \\
\text { Upper Crustal Layer } \\
\begin{array}{l}\text { Deeper } \\
\text { Layer(Moho) }\end{array} \\
\begin{array}{l}\text { Average } \\
\text { thickness }\end{array}\end{array}$ & \begin{tabular}{|l|}
45.15 (FI) \\
$7.41-9.30$ \\
$21.28-21.80$ \\
\\
$33.60-36.47$ \\
\\
35.04
\end{tabular} & $\begin{array}{l}251.94 \\
\text { (FII } \\
7.21- \\
9.77 \\
18.89- \\
22.49 \\
36.25- \\
38.35 \\
\\
37\end{array}$ & $\begin{array}{l}535.60 \quad \text { (FIII ) } \\
6.59-9.49 . \\
17.70-20.26 \\
36.36-37.87 \\
37.12\end{array}$ & $\begin{array}{l}\text { (East of FIII) } \\
4.43-7.98 \\
17.16- \\
18.53 \\
\\
36.29- \\
36.68 \\
36.4\end{array}$ & $\begin{array}{c}\ldots \ldots \ldots \\
\ldots \ldots \ldots \ldots \\
\ldots \ldots \ldots \ldots \\
\ldots \ldots \ldots \ldots\end{array}$ \\
\hline $\begin{array}{l}\text { Traverses-11 } \\
\text { Lattitude } \\
17^{\circ}\end{array}$ & \begin{tabular}{l}
\multicolumn{2}{l}{ Fault Location } \\
Peninsular Gneissis \\
Upper Crustal Layer \\
$\begin{array}{l}\text { Deeper } \\
\text { Layer(Moho) }\end{array}$ \\
$\begin{array}{l}\text { Average } \\
\text { thickness }\end{array}$
\end{tabular} & \begin{tabular}{|l|}
28.55 (FI) \\
$3.06-8.84$ \\
\\
$16.89-20.05$ \\
$34.81-36.65$ \\
35.73
\end{tabular} & $\begin{array}{l}186.84 \\
\text { (FII) } \\
9.50- \\
10.74 \\
\\
19.61- \\
20.64 \\
\\
36.15- \\
37.68 \\
36.78\end{array}$ & $\begin{array}{l}406.24 \text { (FIII) } \\
9.81-11.79 \\
\\
19.86-21.25 \\
\\
34.47-35.49 \\
34.98\end{array}$ & $\begin{array}{l}557.13 \\
\text { (FIV) } \\
8.70- \\
10.98 \\
\\
18.55- \\
19.26 \\
\\
35.61- \\
36.29 \\
35.95 \\
\end{array}$ & $\begin{array}{l}8.81-8.99 \\
18.87- \\
18.89 \\
34.99- \\
35.64 \\
35.32\end{array}$ \\
\hline
\end{tabular}

Figure.14:-Schematicdiagram showing the subsurface crustal configuration (2-D view) along Traverses T1 to T11 of the Dharwar Craton 


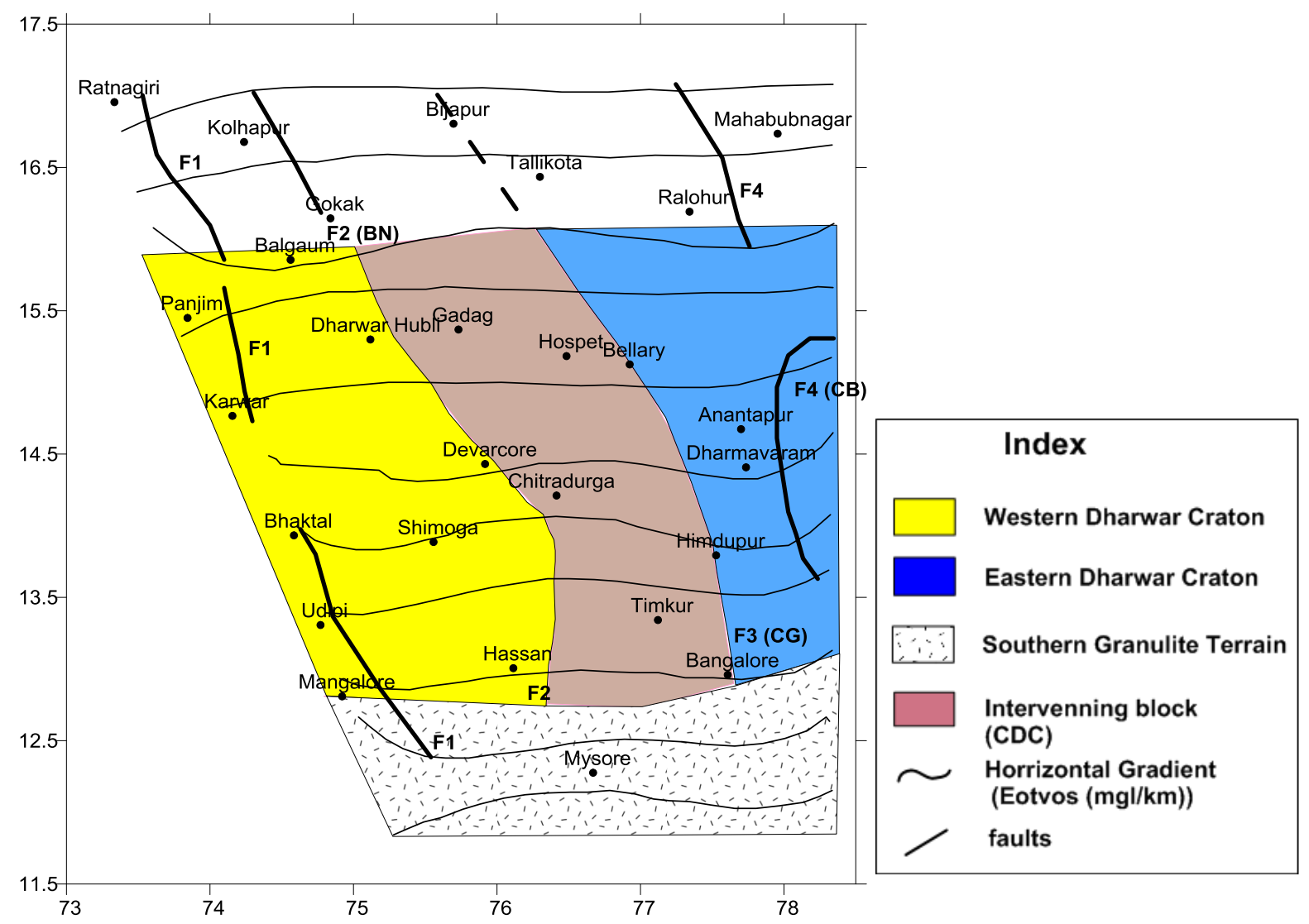

Figure 15:-(a) Schematic diagram showing the evolution of the Dharwar craton along the Traverses T1 to T11 with horizontal gradients and location Faults F1 to FIV).

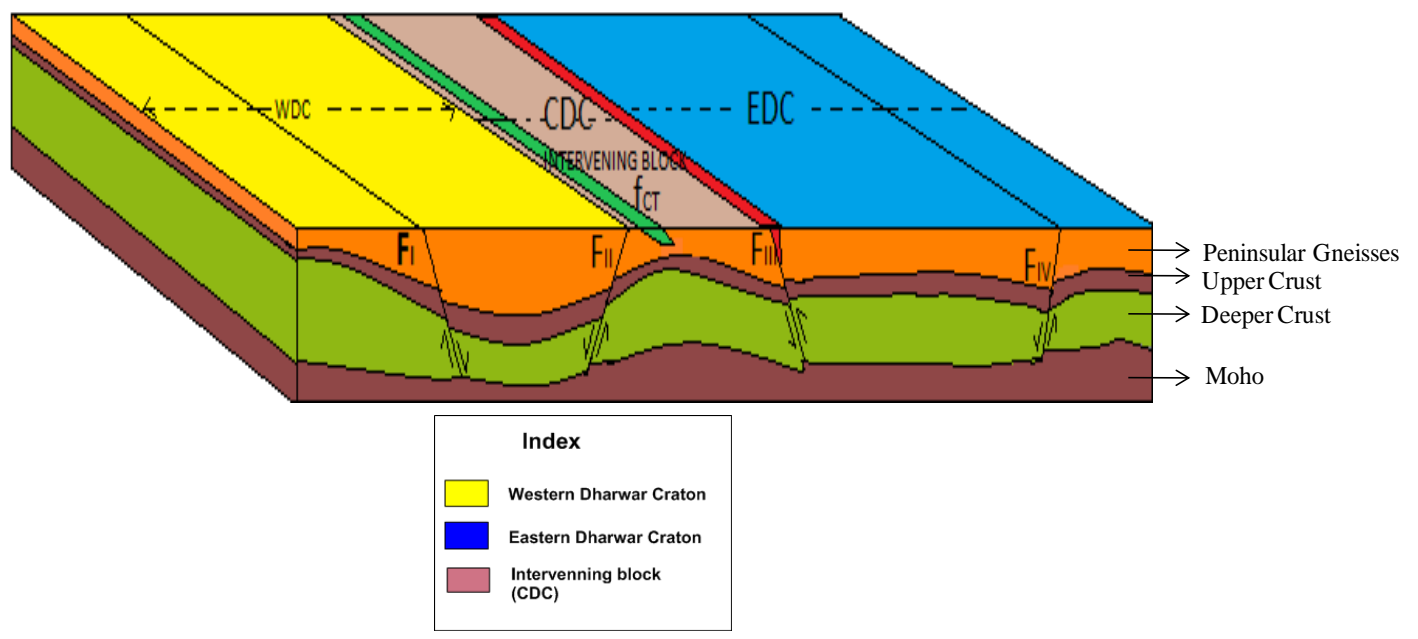

(b) Schematic diagram showing the tectonic classification of Dharwar craton in to Western

Dharwar craton(WDC),Intervening Block (IB) and Eastern Dharwar Craton.

\section{Dharwar Craton: A Discussion:-}

The crustal configuration of the Dharwar cratondrawan from the analysis of the $5^{\text {th }}$ polionomial regional Bougouer gravity analysis along Traverse T1 to T11( Parallel to latitude $12^{\circ}$ to $17^{\circ}$ ) was delineated down to the Moho. The tectonic differentiation has been elucidated on the four layered earth. The four layers as mentioned above consist of 
a top layer of peninsular gneiss $(2.67 \mathrm{gm} / \mathrm{cc}$ ) that forms the basement to the supracrustals, upper crustal layer $(2.72$ $\mathrm{gm} / \mathrm{cc}$ ) and deep crustal layer $(2.85 \mathrm{gm} / \mathrm{cc}$ ) bounded at its lower end by the Moho $(3.3 \mathrm{gm} / \mathrm{cc})$, the layer beneath which constituted the fourth layer.

The basic interpretation guideline is that undulations in the Moho and upwarps/downwarps in the deeper and upper crustal layers correspond to deep seated faults . Four deep seated faults extending down to the Moho were inferred along the traverse $\mathrm{T} 1$ to $\mathrm{T} 11$ ( latitudes $12^{\circ}$ to $17^{\circ}$ ) running ( Fig. 15 a) west to east, Which facilitate the tectonic classification feature of the Dharwar Craton in to the Western Block, Intervening Block and Eastern Dharwar craton Block (Fig 15b).

There is divergence of opinion on the boundary between the western and eastern dharwar. This is variously been considered as the clospet granite batholiths ( Naqvi and Rogers,1987), shear zone west of the clospet granite) Drury and Holt,1980 and Drury et al, 1984,Charwick et al 2000), and as an upthrust zone along the Chitradurga boundary thrust fault ( Kaila et al,1979). Reddy et al (2000), revaluated the craton with seismic wave velocities and suggested that the boundary between the eastern and western Dharwar cratons could be further west of the clopet granite, along the eastern margin of the Chitradurga schist belt.

However, there is reason to define the eastern and western blocks a little differently. Since Intervening block seems to be up thrust, a structure that can only be explained by up warping and consequent faulting at contacts arising due to a geo anticline structures (Narayanaswamy et al, (1970), it is proposed that this intervening block (between F-II to F-III).rather than any linear feature marks the boundary between the eastern and western blocks. Strengthen the hypothesis are the dips and throws of the deep seated faults ( FI- is parallel to FIII and F-II to F-IV), which suggests build up stresses along the two different directions. While, between F-I to FII are down thrown blocks, west of F-I and the Intervening Block are the up thrown blocks. The observed throws for the faulted blocks are $5 \mathrm{~km}$ along F-I, $6 \mathrm{~km}$ along F-II, along F-III and $5 \mathrm{~km}$ along F-IV. (TABLE-I)

Several plate tectonic models have been proposed for the evolution of the Dharwar craton, Naqvi, Manikyamba and associated of NGRI (Naqvi,2005), Kaila et al (1979) believed the Chitradurga thrust boundary to be the boundary between the eastern and western Dharwars, Chadwick et al (1989 \& 1992) suggest that the lower and upper Chitradurga subgroups indicate an active continental margin or micro continental arc while Radhakrishna and Naqvi $(1986,1985)$ suggest that the linear Chitardurga belt is possibly an Achaean suture generated as a result of collision tectonics and closure of oceanic basin between the juvenile continental blocks. However it is felt that this is extremely unlikely as the CT is not a deep seated fault, extending as it does only to the gneissic basement.

A similar tectonic configuration drawn from an analysis of the $5^{\text {th }}$ order polynomial fit for regional gravity along the transect was reported earlier (Ramadass et al, 2006, Himabindu and Ramadass, 2004). Results of radiometric studies in the western and central parts of the transect (Himabindu and Ramadass, 2003) have also corroborated inferences drawn from gravity studies.

A three fold classification as indicated in the above section Figure-15b instead of the currently accepted two fold classification., The crustal thickness in Block Intervening block is perceptibly less than Blocks Western and Eastern DharwrBlcoksalong the traverses from T2 to T9. Such a configuration can only be explained by up warping and consequent faulting at contacts arising due to a geo-anticline structure. Therefore, it is proposed that this up thrown intervening block (IB between faults $\mathrm{F}_{\mathrm{II}}$ and $\mathrm{F}_{\text {III }}$ ), rather than any linear feature, marks the boundary between the eastern and Dharwar blocks. It extends (on its eastern side) to the western margin of the Closepet batholith. The significantly lesser crustal thickness in block IB as compared to EDC and WDC can be explained by a geo-anticlinal structure with upwarping and consequent faulting. Therefore, we propose that this upthrown intervening block I (between faults FII and FIII), rather than any linear feture, marks the boundary between the eastern and western blocks.

The crustal thickness for each of the tectonic sub-blocks identified, viz., west of fault $\mathrm{F}_{\mathrm{I}}$, in between $\left(\mathrm{F}_{\mathrm{I}^{-}} \mathrm{F}_{\mathrm{II}}\right), \quad\left(\mathrm{F}_{\mathrm{II}}{ }^{-}\right.$ $\mathrm{F}_{\text {III }}$, $\left(\mathrm{F}_{\mathrm{III}}-\mathrm{F}_{\mathrm{IV}}\right)$ and (East of $\left.\mathrm{F}_{\mathrm{IV}}\right)$. The corresponding average crustal thickness for the western block WDC is 39 $\mathrm{km}$. On the other hand, the maximum crustal thickness for the eastern Dharwar block EDC is $37 \mathrm{~km}$. The crustal thickness beneath the Chitradurga thrust, which lies roughly in the middle of the intervening block IB is about 34 $\mathrm{km}$. More recent studies by Jayanda et al ( 2013) and Sunder Raju ( 2014) revealed that present Intervening block in between Western and Eastern Dharwar block called as a Central Dharwar block. Mohan et al (2013) support this 
model of Jayanandha et al (2013) and stress the importance of a convergent margin tectonic setting for the Eastern Dharwar craton, the importance of subduction process and supduction arc settings. Western Dharwar Craton (WDC), Eastern Dharwar Craton (EDC) and Intervening Blocks, these results are comparable with those obtained from magneto Telluric studies (Gokarn et al., 1998,2004), Tomography studies (Srinagesh and Roy et al., 1996) and DSS by Reddy et al ,2000 and Gravity studies ( Ramadass et al., 2006,2007) are correspond fairly well this results.

The present configuration of the Western Dharwar craton (WDC) is located west of Intervening block and is bound to the Eastern Dharwar block, to the west by the Arabian Sea, and to the south by a transition into the so called Southern Granulite terrain. The reaming boundary to the north is buried under younger sediments and the Cretaceous Deccan traps.

\section{Conclusions:-}

Results of modeling of $5^{\text {th }}$ order polynomial gravity and magnetic data along traverse-T1 to T11 approximately EW trending, Dharwar craton indicate the presence of deep-seated faults that warrant a modified tectonic classification of the craton. Four deep-seated faults are inferred based on crustal upwellings/downwarps in the inferred crustal section. These faults coincide with the fault separating the Upper Dharwar sediments from the younger granites $\left(\mathrm{F}_{\mathrm{I}}\right)$, the Bababudan-Nallur shear $\left(\mathrm{F}_{\mathrm{II}}\right)$, the western margin of the Closepet batholith $\left(\mathrm{F}_{\mathrm{III}}\right)$ and the fault associated with a crustal upwarp below the east of $\left(\mathrm{F}_{\mathrm{IV}}\right)$.fault.

1. These faults suggest a modified tectonic classification of the Dharwar craton. Accordingly, we have inferred a Western Dharwarcraton ( WDC) bounded on its east by $\mathrm{F}_{\mathrm{II}}$ and an EasternDharwar Craton ( EDC) bounded on its west by $F_{\text {III }}$, with an Intervening block ( IB ) between $F_{\text {II }}$ and $F_{\text {III. }}$.

2. This tectonic classification runs contrary to the current hypotheses, which generally postulate only two sub blocks of the craton - the eastern Dharwar craton and the western Dharwar craton.

3. The Chitradurga fault, hitherto believed to divide the Dharwar craton into the eastern and western blocks, is inferred to extend only to the gneissic basement rather than being deep seated.

4. The average crustal thickness for the Western Dharwar craton (WDC) is $39 \mathrm{~km}$, while for the Eastern Dharwar Crton (EDC) is $37 \mathrm{~km}$ and Intervening block (IB) is $34 \mathrm{Km}$.

\section{Acknowledgments:-}

The authors gratefully acknowledge the financial support extended by the UGC New Delhi for granting RFSMS fellowship and Awarding of UGC Emeritus Professor to Prof. G.Ramadass.

\section{References:-}

1. Appa Rao, M., Chakravarty, R., Ananda Reddy. and Murthy, B.V.S., 1995. Geophysical sudies for identification of structures associated with gold mineralisation in the Hutti-Maski schist belt, Raichur district, Karnatka, India.J. Assoc. Expl.Geophysics, Vol. 16, No.2, pp.85-94.

2. Agarwal,B.NP\& Sivaji,C.H.,1992; Separation of regional and residual anomalies by least square orthogonal polynomial and relaxation tectniques; a performance evaluation. Geophysics. Pros.,40, 143-156.

3. Agocs,W.B., 1951, Least squares residual anomaly determination. Geophysics, 16(4), 686-696.

4. Bhagya.K and Ramadass.G., 2016 Sub-surface Structural Configuration of the chitradurga Schist Belt as Inferred from Bouguer Gravity data analysis ;IOSR Journal of Applied Geology and Geophysics (IOSR-JAGG) Volume 4, Issue 1 Ver. I (Jan. - Feb. 2016), PP 21-32.

5. BHAGYA, K AND RAMADASS. G, Structural inferences from Regional Bouguer Gravity in Southern parts of Deccan Volcanic Province India. International Journal of Natural and Applied Science 2014; 3(2): 10-14.

6. Babu.V.R.R.M. 2001. Plate tectonic history of the Indian plate Nellore-Khammam schist belt. Bengaluru; Indian Academy of Geosciences.PP-1-183

7. Chedwick B., Vasudev.V.N., and Hegde,C.V.2000. The Dharwar craton,Southern India internpreted as the result of Late Archean Oblique Convergeance,Precambrian Research .Vol.9.PP 91-111.

8. Drury.S.A, Harris.n.B.W, Holt.R.W, Reeves-Smith.G.J, and Wightman.R.T, 1984. Precambrian tectonics and Crustal evolution in south India, Jour.Geo., Vol.92, PP.3-20.

9. Drury.S.A, Holt.R.W., 1980. The tectonic framework of the south India craton : A reconnaissance involving L imagery, tectonophysics, Vol.65,PP.111-115. 
10. Gupta, M.L., Sharma, S.R., Sundar, A., Singh, S.B., 1987. Geothermal studies in the Hyderabad granitic region and the crustal thermal structure of the southern Indian shield.

11. Tectonophysics 140, 257-264.

12. Gupta, S., Rai, S.S., Prakasam, K.S., Srinagesh, D., Bansal.B.K.,Chadha, R.K., Preistley, K., Gaur,V.K., 2003. The nature of the crust in southern India: implications for Precambrian crustal evolution. Geolphsical Research Letter,30.

13. Gokarn, S. G., Rao, C. K. and Gautam Gupta, 1998. MT studies over the Dharwar craton, $35^{\text {th }}$ Annual convention and meeting on evolution of continental margins - Process and Potential, pp. 51-52.

14. Gokarn.S.G.,Gupta.G, and C.K.Rao : Geophys 2004. Geoelectric Structure of The Dharwar Craton from magnetotelluric studies; Archean suture identified along the Chitragurga-Gadag schist belt. Geophy.Jou.Int.vol.158 (2) , PP.712-728

15. GM-SYS 2010.Geophysical Processing and Analaysis module of Geo-soft.Inc.

16. Gaur.V.K and Priestley.K.R (1997). Shear wave Velocity structure beneath the Archean gravity around Hyderabad inferred from receiver function analysis proc. India Acad.Sci (Earth and Planet.Sci), 106:pp-1-8.

17. Hari Narayan and Subrahmanyam., 1986; Precambrian Tectonics of the South Indian Shield Inferred from Geophysical Data.The Journal of Geology, Vol. 94, No. 2 (Mar., 1986), pp. 187-198

18. Krishna Brahmam.N., 1993, Gravity relation to crustal structure palaeo-sutures and seismicity of southern India (South of the 16 th parallel). Memoir geological society of India, No.25.PP-165-201.

19. Kaila.K.L., and Bhatia.S.C.,1981. Gravity study along the kavali-Udipi deep seismic sounding profile in the Indian Peninsular Shield : some inferences about the origin of Auothosites and the Eastern Ghats orogeny, Tectonophysics. Jour.Geol.Soc.India.Vol.79 (1981), PP-129-143.

20. Kesawamani,M.Venkateshwarlu,M. Rajanikumar,N.C.Murali,G.Jawahar, A.C.Khare,K. Raghu Ramiah, A.Y.S.R. Chayanulu, V.L.Raju and J.Mohan Rao; Significance of regional gravity surveys in mapping granite greenstone terrains over parts of Eastern Dharwar Craton: Geological Survey of India, No.49,1999.

21. Kaila.K.L., Roy Chowdhury.K., Reddy.P.R., Krisna.V.G., Harinarain, Subbotin.S.I., Sollogub.V.B., Chekunov.A.V., Kharetchko.G.E., Lazarenko.M.A and Ilchenko.T.V., 1979. Crustal structure along the KavaliUdipi profile in the Indian Peninsular Shield from deep seismic sounding . Jou.Geol.Soc.India.Vol.20,PP-307333.

22. Kaila, K.L., Krishna, V.G., 1992. Deep seismic sounding studies in India and major discoveries. Current Science $62,117 \pm 154$.

23. Kumar, A., Hamilton, M.A., and Halls, H.C. 2012. A Paleoproterozoic giant radiating dyke swarm in the Dharwar Craton, southern India. Geochemistry, Geophysics, Geosystems, 13: Q02011. doi:10.1029/2011GC003926.

24. Keshawamani.M.,Raju.V.L., Mohana Rao,T.,1996: Qualitative and structural interpretation of geophysical maps with particular reference to gravity and geophysical maps with particular reference to gravity : Geol.Surv.India.Spl.Pub.,40.pp.195-203.

25. Mishra.D.C and Rao.M.B.S.V.,1993. Thickening of crust under granulite province of south India and associated tectonics based on gravity magnetic study . Geol.Soc.Ind.Mem., 25.Pp-203-219.

26. Mishra, D.C., Prajapati, S.K., 2003. A Plausible model for evolution of schist belts and Western granite plutons of Dharwar Craton, India and Madagascar during 3.0-2.5 Ga : insight from gravity modeling constrained in part from seismic studies. Gondwana Research .6.PP-501-511.

27. Mishra, D.C. and Venkatrayudu, M., 1985. scalar anomaly map of India and a part of Indian Ocean-magnetic crust and tectonic correlation. Geophysical Research Letters. Vol. 12, No. 11, pp. 781-784.

28. Mishra, D.C., VijayaKumar.V and Rajasekhar.F.,(2006). Analysis of Airborne Magnetic and Gravity anomalies of peninsular shield, India integrated with Seismic and Magnetotelluric results and gravity anomalias of Madagaskar, Sri Lanka and East Antarctica. Gondwana.Res., 10; pp: 6-17

29. Mishra,D.C., 2011.Gravity and magnetic methods for geological studies. Principles, Intergated Exploration and Plate tectonics. BS publications.net (Book).

30. Naqvi,S.M., and Rogers,J.J.W., 1987. Precambrian geology of India, Oxford Monographys on Geology and Geophysics, No.6 Oxford Univ. Press, PP-107-116.

31. Qureshy, M.N., Aravamadhu, P.S., and Bhatia, S.C.,1967. Some regional gravity traverses through India. Proc. Symp. UMP. Hyderabad, PP-120-133.

32. Rajamani, V. (1990). Petrogenesis of metabasites from the schist belts of the Dharwar craton: Implications to Archaean mafic magmatism, Jour. Geol. Soc. India, 36, 565 - 587.

33. Reddy, A.G.B., Chandrakala, K., and Sridhar, A.R.,2000. Crustal velocity structure of the Dharwar crato, India. Jour. Geol. Soc. India, Vol.55, PP-381-386. 
34. Reddy, A.G.B.,Mathew, M.P., Baladau Singh. and Naidu, P.S., 1988. Aeromagnetic evidence of crustal structure in the granulite terrance of Tamil Nadu, Kerala. Jour. Gol.Soc.India, Vol.32, pp.368-381.

35. Ramadass G Himabindu D and Srinivasulu N, 2003. Structural Appraisal of the Gadag Schist Belt from Gravity Investigations. Proc. Indian Acad. Sci., Earth \& Planet. Sci., Bangalore, Vol.112, No.4. pp. 577-586.

36. Ramadass G, Ramaprasada Rao IB, Himabindu D and Srinivasulu N, 2002. Pseudo-Surface-Velocities (Densities) and Pseudo-Depth-Densities (Velocities) along Selected Profiles in the Dharwar Craton, India. Current Science, Bangalore., Vol. 82, No.2, pp.197-202.

37. Ramakrishnan, M., Viswanath, M.N and Swaminath, J. 1976;Jour.Geol.Soc.India, Vol.17, PP-97-111.

38. Ramadass G, Ramaprasada Rao I B and Himabindu D, 2006. Crustal Configuration of the Dharwar Craton, India, Based on Joint Modeling of Regional Gravity and Magnetic Data. Jour. Asian Earth Sciences, USA, Vol. 26, pp. 437-448.

39. Ramadass G, Ramaprasada Rao I B and Himabindu D, 2007.Dharwar Craton: Crustal Model from Regional Gravity and Magnetic Signatures. IAGR Memoir No. 10, pp. 227-232.

40. Rai,S.S., Priestly,K., Suryaprakasam , K.,Srinagesh.D. Gaur.V.K and Duz ,2003; Crustal shear velocity structure of the South India Shield, Jour.Geophy.Res., Vol.108, B2.2088.doi;10,1029/2002JBoo1776.

41. Radhakrishna M. , P.J. Kurian, C.G. Nambiar, B.V.S. Murty Nature of the crust below the Southern Granulite Terrain (SGT) of Peninsular India across the Bavali shear zone based on analysis of gravity data. Precambrian Research 124 (2003) 21-40

42. Ramakrishnan, M. and Vaidyanadhan, R., 2008. Geology of India Volume-I. Geological Scociety of India, Bangalore.

43. Sarkar, D., Kumar, M. R., Saul, J., Kind, R., Raju, P.S., Chadha, R.K. and Shukla,A.K. (2003) A receiver function perspective of the Dharwar Craton (India) crustal structure. Geophys.J. Int., v. 154, pp. 205-211.

44. Srinagesh, D., and S. S. Rai. Teleseismic tomographic evidence for contrasting upper mantles in South Indian Archean terrains. Phy.l'. lOan!: Planet. Intel:; 97, 22-41. 1996

45. Santosh, M., Yokoyama, K., Biju-Sekhar, S., Rogers, J.J.W., 2003. Multiple tectonothermal events in the granulite blocks of southern India revealed from EPMA dating: implications on the history of supercontinents. Gondwana Research 6, 29-63.

46. Santosh, M., Tanaka, K., Yokoyama, K., Collins, A.S., 2005. Late Neoproterozoic-Cambrian feisic magnetism along transcrustal shear zones in southern India: $\mathrm{U}-\mathrm{Pb}$ electron microprobe ages and implications for the amalgamation of the Gondwana supercontinent. Gondwana Research 8, 31-42.

47. Swami Nath J., Ramakrishnan ,M and Viswanatha, M.N.,1976. Dharwarstratigraphic model and Karnataka, Mem.Geol.Soc.India, No.112, PP.328.

48. Singh, A.P., Mishra, D.C., Laxman, G., 2003 Apparent Density Mapping and 3-D Gravity Inversion of Dharwar Crustal Province. J.Ind. Geophys.Union,Vol.7. No.1,pp.1-9.

49. Singh, A.P., Mishra,D.C., Gupta,S.B., Rao. and M.R.K.P., 2004. Crustal structure and domain tectonics of the Dharwar Craton (India): insight from new gravity data. Journal of Asian Earth Sciences, Vol.23,

50. Subramanyam, C., 1978. On the relation of gravity analysis togeotectonics of the Precambrian terrain of southern Indian Shield; J.Geol. Soc. India, Vol.19, pp. 251 --263. 